\title{
Türkiye Örnekleminde Veri Gazeteciliği Uygulamaları ve Demokrasi İlişkisi Üzerine Bir Değerlendirme
}

\section{Reviewing the Relationship Between Democracy and Data Journalism Practices in Turkey}

\author{
Özlem ERKMEN ${ }^{1 \oplus}$
}

${ }^{1}$ Asst. Prof. Dr., Doğuş University, Faculty of Arts and Sciences, Department of Communication Sciences, İstanbul, Turkey

ORCID: 0000-0001-8761-5099

\section{Sorumlu yazar/Corresponding author: Özlem Erkmen, \\ Doğuş Üniversitesi, FEF İletişim Bilimleri Bölümü, İstanbul, Türkiye \\ E-posta/E-mail: oerkmen@dogus.edu.tr \\ Geliş tarihi/Received: 17.01.2020 Revizyon talebi/Revision Requested: 04.04.2020 \\ Son revizyon teslimi/Last revision received: 01.06 .2020 \\ Kabul tarihi/Accepted: 05.06.2020}

Atıf/Citation: Erkmen, O. (2020). Türkiye örnekleminde veri gazeteciliği uygulamaları ve demokrasi ilişkisi üzerine bir değerlendirme. Connectist: Istanbul University Journal of Communication Sciences, 58, 65-103.

https://doi.org/10.26650/CONNECTIST2020-0007 öz

Dijitalleşmeyle birlikte ortaya çıkan, mevcut yazııımlar veya insan kaynağıyla makul sürelerde işlenemeyen büyük veri yığınları, insanların dünya meselelerine yaklaşımını dönüştürerek demokrasiyi geliştirme potansiyelini barındırmaktadır. Ancak bunun için, veriyi anlamlandıracak, içinde saklanan hikâyeleri kamu yararına ortaya çıkaracak "dijital bekçi köpekleri" (Felle, 2015; 2016) olarak veri gazetecilerine ihtiyaç vardır. Büyük verinin gazetecilik bağlamında tartışıması 2010'daki Wikileaks sızıntısıyla başlamıştır. Veriyi temizleme, düzenleme, görselleştirme, işleme ve ilişkilendirme aşamalarını kapsayan yeni bir pratik olarak veri gazeteciliği öne çıkmıştır. Özellikle gayrı resmi/gizli verilerden hareketle 'gölgelerde saklı olanı' arayan, veriyi sorgulayıp içindeki ilişkileri bulmayı içeren araştırmacı veri gazeteciliği, demokrasinin önemli bir aracı olarak vurgulanmaktadır. Araştırma, veri gazeteciliğinin bu işlevini Türkiye örneklemindeki uygulama bağlamında tartışmaktadır. Betimsel araştırma yöntemi ile yapılan çalışmada derinlemesine görüşme ve içerik analizi teknikleri kullanılmıştır. Bu doğrultuda, veri projesi üretimine dâhil olmuş gazetecilerle derinlemesine görüşmeler yapılmış, ayrıca Global Editors Network tarafından düzenlenen veri gazeteciliği ödüllerine Türkiye'den başvuran projelerin içerik ve teknik özellikleri incelenmiştir. Araştırma bulguları, veri gazeteciliğinin çoğunlukla küçük ölçekli ve alternatif haber merkezleri tarafından, daha çok hak odaklı perspektifle yapılan bir pratik olduğunu göstermektedir. Ancak yayınlanabilir konulara yönelme baskısı ve zamansızlık, yapılanı 'hesap soran' bir gazetecilik olmaktan uzaklaştırmaktadır. Türkiye örnekleminde veri gazeteciliğinin demokratikleştirici potansiyelini gerçekleştirmesinin önündeki diğer engeller olarak, medyanın henüz veri gazeteciliğine yatırım yapmaması, güvenilir veriye erişilememesi, mesleki işbirliğinin kısıtılığı, yurttaş katılımlı alternatif fonlama ve haber üretme mekanizmalarının gerçekleştirilememesi sayılabilir.

Anahtar Kelimeler: Veri gazeteciliği, şeffaflık, demokratikleşme, hesap sorulabilirlik, açık toplum 


\begin{abstract}
Large data stacks that emerged with digitalisation, which could not be processed in a reasonable time with existing software or human resources, have the potential to develop democracy by transforming people's approach to world affairs. However, there is a need for data journalists as "digital watchdogs" (Felle, 2015; 2016) that will make sense of the data and reveal the stories hidden in it for public good. The discussion of big data in the context of journalism started with the Wikileaks in 2010. Data journalism has come to the fore as a new practice covering the stages of cleaning, editing, visualising, processing and contextualising data. Investigative data journalism, which seeks to "find what is hidden in the shadows" based on informal/confidential data, and to find the relationships in it, is emphasised as an important tool of democracy. The study discusses this function of data journalism in
\end{abstract}

Turkish context. In-depth interviews with data journalists have been made, along with the examination of content and technical characteristics of the projects applied from Turkey to the Global Editors Network's Data Journalism Awards. The findings show that data journalism is mostly practised by small-scale and alternative newsrooms, with a human rights-based perspective. However, time shortage and the pressure of preparing publishable stories, prevent journalists from practising accountability journalism. Other obstacles to data journalism to fulfil its democratising potential are; media institutions do not invest in data journalism, accessing reliable data is difficult, professional collaboration is limited, and crowdsourcing for funding and/or news making is not applicable..

Keywords: Data journalism, transparency, democratisation, accountability, open society

\section{EXTENDED ABSTRACT}

Since the beginning of the 20th century, developments in information and communication technologies have radically transformed and digitised our daily lives. Every individual in the digital ecosystem, continually participates in data production by leaving digital traces. These data stacks, which could not be processed in a reasonable time with existing software or hu-man resources, are called big data. Those who are pro-big data, emphasise its potential to im-prove our understanding and perception of world affairs. However, there is a need for data journalists to be "digital watchdogs" (Felle, 2015; 2016) that will make sense of the data and reveal the stories hidden in them for the public good.

The discussion of big data in the context of journalism started with the Wikileaks in 2010. Data journalism has come to the fore as a new practice covering the stages of cleaning, edit-ing, visualising, processing and contextualising data. Investigative data journalism (Mair, \& Keeble, 2013), which seeks to "find what is hidden in the shadows" based on infor-mal/confidential data, and to find the relationships in it, is emphasised as an important tool of democracy. Both professionals and academics assume that; the media, which has been grad-ually losing blood under the influence of neoliberal, conservative and authoritarian govern-ments, could regain the fourth power function with the aid of investigative data journalism. 
Accordingly, case studies on how this practice is implemented in different countries are fre-quently conducted. Although the pioneering studies focus on the United States and European countries, the practice in the global south with different media systems has been questioned recently (Mutsvairo, 2019; Palomo, Teruel, \& Blanco-Castilla, 2019).

Academic interest in data journalism in Turkey started in the second half of the 2010s, con-currently with early examples of data journalism pieces. However, the number of journalists and data stories produced, as well as the number of academic studies on the subject are quite limited. Since data journalism is at an early stage, academic works are rather descriptive stud-ies that relate data journalism to the transformation of journalism in the context of digitisation. On the other hand, a small number of MA and PhD thesis on the subject seek to interrogate the practice in Turkey with media professionals (Bayraktar, 2018; Furuncu, 2019; Oran, 2018). Those studies conclude that the practice of data journalism is weak in Turkey, and at-tribute this mainly to the lack of interest shown by media outlets in data journalism practice and training, and to the difficulties of accessing open data.

The study discusses the potential of data journalism to strengthen democracy and journal-istic autonomy in a Turkish context. In-depth interviews with data journalists were made, along with the examination of content and technical characteristics of the projects applied from Turkey to the Global Editors Network's Data Journalism Awards (DJA). The interviewees were determined using snowball sampling. DJA applicants and journalists who participated in training organised by the Dokuz8 Haber citizen journalism platform were first contacted. The interviewees were then asked to propose people who they knew were reporting on data. In this way, interviews were conducted with eight people involved in data projects. Half of the interviewees were print and online media employees; the other half were independent or freelancers. The findings show that data journalism is mostly practiced by small-scale and alternative news-rooms, with a human rights-based perspective. However, time shortage and the pressure of preparing publishable stories, prevent journalists from practising accountability journalism. Other obstacles to data journalism to fulfil its democratising potential can be summarised in three categories:

Firstly, there are structural problems related to ownership and power relations. The mainstream media is not yet aware of data journalism or ignores data due to their editorial policies; and alternative media in its turn, struggles with legal issues and 
censorship. In addition, the monopolisation of data and the problems stemming from the Turkish Statistical Institute's methodology make access to reliable data difficult. Secondly, there are problems related to the working conditions of journalists. Due to economic and editorial requirements, media organisations do not employ full-time data staff, and they are also uninterested in training existing staff. Furthermore, the interviewees complain about time pressure and a lack of professional collaboration. Finally, problems related to social structure and education level can be mentioned. Crowdsourcing/crowdfunding are not applicable because data journalism lacks the broad and dedicated audience it needs to realise it. It seems that the audience is a very limited digital literate elite.

Research findings show that, even though data journalists feel responsible for informing cit-izens on the stories that the data contains, they are far from being digital watchdogs. At the same time, alternative funding and news making mechanisms with citizen participation that will reinforce journalistic autonomy have not been implemented yet. At this point, data journalism cannot fulfil its function of strengthening democracy and encouraging democratic processes. The conditions highlighted by the interviewees do not indicate a positive development in these areas in the short term. 


\section{GíRiş}

Yaşamakta olduğumuz yüzyılın başından beri, bilgi ve iletişim teknolojilerindeki gelişmeler neticesinde, profesyonel, siyasal, toplumsal ve gündelik yaşamlarımız hızla 'verileşmektedir.' Özellikle 'nesnelerin interneti,' yani pek çok akıllı cihazın internet altyapısıyla birbirine bağlanarak kullanıcılarına ve birbirlerine bildirimler göndermesi, veri alışverişini hızlandırmıştır. Bu akıllı cihazlarla olan etkileşimimiz, günlük hayatımızın her aşamasında sayısal izler bırakmamıza neden olmaktadır. Bu yolla her gün çok farklı kaynaklardan, daha önce görülmemiş miktarlarda veri üretilmektedir. İnsan gücüyle veya mevcut bilgisayar yazılımları vasıtasıyla toplanması, işlenmesi veya analiz edilmesi makul sürelerde mümkün olamayacak boyutlardaki bu veri, 'büyük veri' olarak adlandırımaktadır.

Büyük veri karşısında iki farklı tutumdan bahsetmek mümkündür. Şüpheciler olarak niteleyebileceğimiz ilk grup, aslen ekonomik piyasalarda herkes tarafından bilinmediği için sağlıklı bir rekabet ortamı oluşmasını engelleyen ve piyasa şartlarını bozan bilgilerden bahsederken kullanılan bilgi asimetrisi kavramına göndermeyle, bilginin üretildiği kadar hızlı işlenememesi yüzünden herkesin büyük veriden eşit biçimde faydalanamayacağını öne sürerler. Destekçiler olarak niteleyebileceğimiz ikinci grup ise, büyük verinin dünya meselelerine dair anlayış ve algımızı geliştirme potansiyeline vurgu yapmaktadır (Erkmen, 2018). Büyük verinin hâkimiyetindeki dijital çağda, hakikatötesi, yalan haber, yankı odası vb. kavramların gölgesinde, gazeteciliğe ve medyaya olan güven hızla yok olurken; gazeteciliğin rolünün ne olması gerektiği de tekrar ve tekrar sorgulanmaktadır (Esser, \& Neuberger, 2019; Lewis, 2015). Yurttaşların daha iyi bilgilenmesi ve demokratik tartışmaları donanımlı biçimde sürdürebilmeleri için, büyük veri yığınlarının içinde kaybolmadan anlamlı hale getirilebilmesi gerekmektedir. Bu bakış açısına göre, veri gazetecileri bu işlemi yurttaşlar için gerçekleştirebilecek aracılar olarak öne çıkmaktadır. Bu aracı rolünün aynı zamanda gazetecilere neoliberal, muhafazakâr ve otoriter hükümetlerin etkisindeki medya rejimlerinde çoktandır kaybetmiş oldukları geleneksel "bekçi köpekliği" yükümlülüğünü de yeniden yüklemektedir. Ancak bu sefer kendilerinden "dijital bekçi köpekleri"(Felle, 2015; 2016) olmaları beklenmektedir.

Büyük verinin gazetecilik bağlamında tartışıması ve veri gazeteciliği kavramının ortaya çıkması 2010 tarihli Wikileaks sızıntısı sonrası olmuştur. Wikileaks sonrası, ham veri kümelerinin işlenerek sıradan okuyucu için anlamlı kılınması yoluyla şeffaflık, 
demokrasi ve kamu yararı sağlanabileceği (Baack, 2011, pp. 2-4), ayrıca veriye dayandırmanın haberin nesnelliğini arttırarak okuyucuların medyaya yönelik güvenini tazeleyebileceği (Rogers, Schwabish, \& Bowers, 2017) fikirleri tartışılmaya başlanmıştır. Hatta Web'in babası olarak nitelenen Tim-Berners Lee bu bağlamda veri gazeteciliğinin, mesleğin geleceği olduğunu dahi belirtmiştir (Arthur, 2010). Bu ortamda verinin içinde gizli olan haber hikâyelerini ortaya çıkarmak, veriyi açıklamak veya mevcut haber hikâyelerini veriyle zenginleştirip doğrulamakla ilgilenen medya kuruluşlarının sayısı her geçen gün artmaktadır.

Kavramsal tartışmada veri gazeteciliğinin yeni bir tür gazetecilik pratiği olmaktan ziyade, haber hikâyelerini oluşturmak üzere başvurulan, yeni teknolojilere dayalı yeni bir tür beceri setini gerektiren bir eğilim olduğuna dair görüşler ağır basmaktadır. Bilgisayarların ve elektronik hesap tablolarının gazetecilikte kullanımının yaygınlaşması, internetin gelişimi, elektronik kaynak ve arşivler yoluyla veriye erişmenin kolaylaşması, veri setlerini daha anlaşıır kılmak için görselleştirilmesine olan ilginin artması, açık veri hareketi ile bilgi edinme düzenlemeleri gibi gelişmeler bu pratiği mümkün kılmıştır (Hewett, 2013; Rogers, 2013). Veri gazeteciliğinin teknolojik öncüllerinin, 1960'ların sonunda uygulanmaya başlanan bilgisayar destekli gazetecilik ve bilimsel gazetecilik olduğu düşünülmektedir. Bilimsel gazetecilik yaklaşımından bilimsel nesnellik vurgusunu ve veri analizi kullanmasını, bilgisayar destekli gazetecilikten de veri tabanları ve hesap tablolarının kullanımını ödünç aldığı söylenebilir. Günümüzde bunlara API'ler (uygulama programlama arayüzü), veri görselleştirme araçları ile hacker kültürü de eşlik etmektedir (Erkmen, 2018). Bunlardan faydalanarak, verinin analiz edilmesi ve bu analizin görsel olarak sunulması yoluyla haber hikâyelerini aktarmayı amaçlayan veri gazeteciliği ham veri setlerini herkesin anlayabileceği içeriklere dönüştürmek üzere; veriyi toplama, filtreleme, düzenleme, görselleştirme, işleme, bir bağlama oturtma ve ilişkili veri setleriyle birleştirme (ilişkilendirme) aşamalarından oluşan bir süreç izler. Veri gazeteciliğinin en önemli özelliklerinden biri de, gazetecilerden kendi çalıştıkları veri setlerini de paylaşmalarını talep eden yanıyla medyayı da daha şeffaf kılma potansiyelini taşımasıdır. Süreç sonunda üretilen içeriklerin toplum üzerindeki etkilerini; haber alma özgürlüğü, şeffaflık ve demokratikleşme ile bağlantısı çerçevesinde değerlendirmek mümkündür

Araştırma Türkiye örnekleminde veri gazeteciliği uygulamasına odaklanırken, bu pratiğin ülkede demokratik kültürü ve gazeteci özerkliğini güçlendirebilme potansiyelini yukarıda anılan bağlamda tartışmaya açmaktadır. Çalışmaya kaynak teşkil eden veriler, iki farklı teknikle toplanmıştır. İlk olarak gelişmekte olan veri gazeteciliği pratiğine dâhil 
olan, veri projesi/haberi üretmiş gazetecilerle yarı yapılandırılmış görüşmeler yapılarak, veri gazeteciliğinin habercilik ekosistemindeki yeri ve uygulamada karşılaşılan sorunlar ortaya konmaya çalışıımıştır. Bunun yanında Global Editors Network (GEN) tarafından her yıl düzenlenen veri gazeteciliği ödüllerine Türkiye'den başvuran projeler ilgili başlıklar altında incelenerek, veri haberlerinde ele alınan konular ve haberlerin teknik ve içerik özellikleri tespit edilmiştir.

Illk bölümde veri gazeteciliği ile demokrasi arasındaki ilişki ortaya konmakta, ayrıca Türkiye'nin güncel medya tablosu içinde veri gazeteciliğinin demokrasi açısından taşıdığı potansiyellere değinilmektedir. İkinci bölüm çalışmanın metodolojik yaklaşımını ortaya koymakta, üçüncü bölümde ise elde edilen bulgular tartışılmaktadır. Bu bölümdeki alt başlıklarda sırasıyla veri haberlerini yapanlar, bunların çalışma koşulları, haberlerin teknik ve içerik özellikleri aktarılmaktadır. Ayrıca veri gazeteciliğinin demokratikleştirici potansiyeli açık veri, şeffaflık ve hesap sorulabilirlik, nesnellik ve gazeteci özerkliği ile katılım ve etkileşim boyutlarıyla tarış̧ımaktadır. Bu bölümde son olarak veri gazeteciliğinin ülkedeki gelişiminin sunduğu fırsatlar ve önündeki engeller ortaya konmaktadır. Çalışmanın sonuç bölümünde ise, Türkiye örnekleminde veri gazeteciliğinin geliştirilebilmesi ve açık toplum ile demokrasi yönündeki çabalara katkı sağlayacak bir pratik olarak ortaya konulabilmesi için öneriler sunulmaktadır.

Veri gazeteciliği ile ilgili literatür tarandığında, kavramın Wikileaks sonrasında ilk olarak teknolojik gelişme ve dijitalleşme çerçevesinde tartışılmaya başlandığı; daha sonra pratiği ifade özgürlüğü, şeffafık ve demokrasiyle ilişkilendiren çalışmaların ağırlık kazandığı görülmektedir. Veri gazeteciliğiyle ilgili öncü çalışmaların ağırlığı Amerika ve Avrupa ülkelerinde olsa da (Borges-Rey, 2016; Paraise, \& Dagiral, 2012; Tabari, Provost, \&Trottier, 2016), son dönemde farklı medya sistemlerine sahip küresel güney ülkelerindeki pratik de özellikle demokrasiyle ilişkisi bağlamında sorgulanmaya başlanmıştır (Mutsvairo, Bebawi, \& Borges-Rey, 2019; Palomo, Teruel, \& Blanco-Castilla, 2019; Rodriguez, 2015; Wright, Zamith, \& Bebawi, 2019). Türkiye'deyse ilk profesyonel veri gazeteciliği işleri gibi akademik ilgi de on yılın ikinci yarısında artmıştır. Ne var ki bu işi yapan gazeteci ve üretilmiş veri haberi sayısı da, konuyla ilgili yapılmış akademik çalışma sayısı da kısıtlıdır. Veri gazeteciliği pratiğinin henüz başlangıç aşamasında olmasından ötürü, yapılmış akademik çalışmalar da daha ziyade, veri gazeteciliğini dijitalleşme bağlamında gazeteciliğin dönüşüm süreciyle ilişkilendiren tanımlayıcı çalışmalardır. Örneğin Narin ve arkadaşlarının (2017) veri gazeteciliğini büyük veriyle, Doğu'nun (2015) da demokrasi ile ilişkisi çerçevesinde tartışan çalışmaları, bu çalışmanın kavramsal çerçevesine de 
katkı sunmuştur. Diğer yandan üniversitelerin lisansüstü programlarında üretilmiş az sayıdaki tezde ise konunun medya profesyonelleri ile Türkiye'deki pratik çerçevesinden tartışılmaya başlandığı görülmektedir (Bayraktar, 2018; Furuncu, 2019; Oran, 2018). Bu çalışmaların ortak noktası Türkiye'de veri gazeteciliği pratiğinin zayıf kaldığını belirtmeleri ve bu durumu gazetecilerin veri gazeteciliği konusundaki eğitim yetersizliğine, medya kuruluşlarının bu konuya ilgisizliğine ve açık veriye erişimin zorluklarına bağlıyor oluşlarıdır.

Uluslararası literatürde veri gazeteciliğinin farklı ülkelerdeki uygulamasına dair vaka analizlerine sıklıkla rastlanmakla birlikte, Türkiye incelenmesi zor bir vaka durumundadır. Bunun birkaç sebebinden bahsetmek mümkündür. Öncelikle ülkede veri gazeteciliği uygulaması henüz başlangıç aşamasındadır ve üretilmiş çok az iş vardır. İincisi kendini veri gazetecisi olarak tanımlayan kişiler de üretilmiş işler kadar azdır ve bu kişilerin büyük bir kısmının yayınlanmış veri haberi bulunmamaktadır. Mevcut çalışma, Türkiye'deki medya ortamından ve pratikten kaynaklı kısıtılıkları barındırmakla birlikte, veri gazeteciliğinin demokrasi ile olan ilişkisini Türkiye örneklemindeki uygulamadan hareketle tartışan ilk araştırma olma özelliğini taşımaktadır. Henüz gelişme aşamasında olan Türkçe veri gazeteciliği literatürüne, hem veri gazeteciliğinin Türkiye örnekleminde demokratikleşme adına sunduğu fırsatlar ve önündeki engelleri ortaya koyarak; hem de açık toplum ile demokrasi yönündeki çabalara katkı sağlayacak bir pratik olarak ortaya konulabilmesi için öneriler sunarak katkıda bulunmak amacındadır.

\section{Veri Gazeteciliği ve Demokrasi illişkisi}

Liberal demokratik toplumlarda, liberal basın teorisinin medyaya yüklediği dördüncü güç veya bekçi köpeği işlevine de zemin oluşturan güçler ayrılığı ilkesinin korunmasına yönelik düzenlemeler yapılmaktadır. Mesela Avrupa İnsan Hakları Sözleşmesi ile Birleşmiş Milletler Medeni ve Siyasi Haklar Sözleşmesi gibi ulusötesi sözleşmelerde ifade ve basın özgürlüğü tanınmakta ve hiçbir şekilde kısıtlanmaması gerektiği belirtilmektedir. Bu doğrultuda çok sayıda ülkede, gazetecilerin hükümetleri araştırma ve eleştirme özgürlükleri tanındığı gibi, Bilgi Edinme Hakkı düzenlemeleri gibi şeffaflaştırıcı yasalar hayata geçirilmiştir. Ne var ki, bahsi geçen yasal metinlere tabi ülkelerde bile; terörle mücadele düzenlemeleri, propaganda, dezenformasyon, hükümetlerin gözetim, takip ve denetimi gibi uygulamalar sansürün çeşitli biçimlerine dönüşmekte, ifade özgürlüğünü baskılarken gazeteciliği de bekçi köpeği olma noktasında gittikçe daha işlevsiz hale getirmektedir (Carlsson, \& Pöyhtari, 2017, p. 12). 
Veri gazeteciliğinin sansür karşısında gazeteciliğe yitirildiği söylenen bu işlevlerini tekrar kazandırabilecek demokratikleştirici bir uygulama olduğu düşünülmektedir (Baack, 2015; Paraise, \& Dagiral, 2012). Bunun birkaç sebebinden bahsetmek mümkündür. Öncelikle yurttaşların kendi verilerini yaratarak ya da analiz ederek sürece katılmasına olanak sağladığından katılımcı ve etkileşimlidir. Diğer yandan kamu kurumlarının çalışma alanlarına yönelik verileri açık olarak paylaşması yönünde baskı oluşturarak, hem kurumlar arasındaki iletişimi kolaylaştırmakta, hem de kurumları hesap sorulabilir kıldığından verimliliklerinin artııımasında dolaylı katkı sağlamaktadır. Ayrıca bu yolla medya kuruluşlarının derinlemesine araştırmaları daha az maliyetle yürütmesine ve gazetecilerin haber hikâyelerini somut veri ve delillere dayandırmalarına imkân sağladığından gazeteci nesnelliğini güçlendirmektedir. Veri setindeki anormallikler üzerinden araştırma soruları bulmak, böylece geleneksel enformasyon toplama yollarıyla edinemeyeceğimiz, ilgililerin üzerini örtebileceği haber hikâyelerini ortaya çıkarmak mümkündür. Diğer yandan veri haberdeki olayın tekil bir vaka olmadığını ortaya koyduğu için de klasik haberden daha güçlü bir etki yaratmaktadır.

Veri gazeteciliğinin yukarıda bahsedilen işlevleri üstelenebilmesi, nitelikli verinin herkes için ulaşılabilir kılınmasıyla yakından ilişkilidir. Nitekim Birleşmiş Milletler, on yıın başından beri dünyanın ger yerinde insanlar için daha iyi bir gelecek yaratılması konusunda, yurttaşlara sunulan verinin açık ve şeffaf kılınmasının ve niteliğinin arttırılmasının önemini vurgulamakta, "sürdürülebilir kalkınma için Veri Devrimi" çağrısı yapmaktadır ("A world that...," 2014). Keza Open Knowledge Foundation (Open Knowledge Foundation, n. d.) da verinin herkesin erişebileceği şekilde ve işlenmeye uygun formatlarda ulaşılabilir kılınmasının; farklı veri kümeleriyle birleştirilebilmesinin, farklı kullanımlarının ve dolaşımının serbest bırakılmasının; devlet sırrı, telif veya ticari amaçlı kullanım da dâhil olmak üzere hiçbir kısıtlama olmaksınız evrensel katılımının sağlanmasının önemini vurgulamaktadır. Baack (2015) açık verinin demokratik değerleri ve yurttaş etkinliğini desteklemesinin üç koşulundan bahseder. Buna göre ortalama yurttaşın yorumlayacak zamandan ve uzman bilgisinden yoksun olduğu açık veriyi, onlar için anlamlandıran veri gazetecileri önemli aracılardır. Okuyucuyla kuracakları işbirliği gazeteciliğe de yurttaşa yakın ve demokratik bir işleyiş kazandıracaktır. Verinin erişilebilir kılınması ve kamuya mal edilmesi yönetimi şeffaflaştıracağı için kamu yararınadır. Ancak verinin açık hale getirilmesi, demokratikleştirme için tek başına yeterli olmamaktadır, bu veriyi işlemek ve onu herkesin anlayabileceği ve gündelik yaşamda faydalanabileceği bir içeriğe dönüştürmek gerekmektedir. Buna göre gazetecilerin görevi haberi en önce vermek değil; soyut verileri herkesin kendisiyle ilişkilendirebileceği 
şekilde somut bilgilere dönüştürmek ve haberin okuyucular için ne anlama geldiğini açıklamak olarak kabul edilmektedir (Lorenz, Kayser, \& McGhee, 2011). Bu sayede ham verinin içeriğine vakıf olan yurttaşların, yöneticileri daha iyi kontrol etmesi de, kendi rasyonel değerlendirmelerini yapabilmesi de mümkün gözükmektedir (Baack, 2015; Doğu, 2015). Doğu (2015) veri gazeteciliğinin demokrasiyle olan ilişkisine yukarıda sayılan boyutların yanı sıra ayrıca, kitle kaynak kullanımı boyutunu da eklemektedir. Buna göre yurttaşların verinin hem toplanma hem de işlenme süreçlerine dâhil olabilmesi, veri gazeteciliği süreçlerini de daha katıımcı ve demokratik kılmaktadır.

Veri gazeteciliğinin uygulanmasında iki ana akım vardır: genel veri gazeteciliği ve araştırmacı/soruşturmacı veri gazeteciliği. İlkinde, gazeteci haber hikâyelerini kısıtlı zamanda, kamuya açık veri kaynaklarından ve temel sayısal becerilerden faydalanarak üretir veya haber anlatısını desteklemek için veriden faydalanır. İkincisindeyse, haber hikâyelerinin ortaya çıkması uzun süreli bir araştırma gerektirir. Gazeteci sızıntılardan veya gayrı resmi/gizli verilerden yola çıkarak "gölgelerde saklı olanı" bulmaya çalışır, bu nedenle farklı kaynaklardan teyit ve sağlama yapmak zorundadır. Bu da ileri düzeyde dijital okuryazarlık gerektirmektedir. Geleneksel araştırmacı gazetecilik ruhuyla yapılan bu çalışma yoğun olarak veriyi sorgulamayı ve içindeki ilişkileri bulup şekillendirmeyi de içermektedir ve bu özellikleriyle demokrasinin önemli bir aracı olarak görülmektedir (Mair, \& Keeble, 2013). Bu doğrultuda çalışmada, Türkiye örnekleminde araştırmacı veri gazeteciliği pratiğinin güncel durumu ortaya konmaya ve demokratikleşme ile ilişkisi bağlamında tartışıımaya çalışılmıştır.

Media Ownership Monitor Türkiye verilerine göre, 2019 yılı itibarılla Türkiye'nin izleyici oranları bakımından en büyük 40 medya organizasyonunun 2/3'ü enerji, inşaat, madencilik ve turizm gibi alanlarda faaliyet göstermekte olan holdinglere dâhildir (Media Ownership Monitor, 2019). Genellikle hükümetin çizgisinde haberler yayınlayan ana akım medyada var olabilmek, özellikle eleştirel, araştırmacı gazeteciler için gittikçe zorlaşmış durumdadır. Ana akımdan çıkarma veya istifalar nedeniyle ayrılan pek çok gazeteci, alternatif mecralarda veya kişisel sosyal medya hesapları yoluyla gazetecilik faaliyetlerini sürdürmeye devam etmektedir (Ataman, \& Çoban, 2019). Alternatif medya kuruluşlarının da kapatmalar veya cezai yaptıımlarla mücadele ettiği medya ortamında, sadece veri haberleri üretmeye yönelik veya datablog şeklinde düzenli veri haberi üreten medya kuruluşu da bulunmamaktadır. Yalnızca az sayıda medya kuruluşu, veri gazeteciliği konusunun üzerine eğilmekte ve çeşitli fonlara dayanan projeler kapsamında veri haberleri üretmeye çalışmaktadır. Bu noktada verinin toplanmasını, temizlenmesini, 
işlenip görselleştirilmesini içeren veri projeleri nedeniyle Dağ Medya, Newslab Turkey ve Journo bahsedilmesi gereken örnekler olsa da, halen üretilebilen kapsamlı veri haberi sayısı oldukça sınırlıdır. Yine de bu ortamda araştırmacı veri gazeteciliği yapmanın ne kadar mümkün olduğu ile bu pratiğin demokratikleştirici potansiyelini Türkiye örnekleminde ne derece gerçekleştirebileceği bu araştırmanın cevap aradığı temel sorulardır. Çalışmadaki kuramsal tartışma Özlem Erkmen'in (2018) “Büyük Veri ve Gazetecilik:Veri Gazeteciliği Demokrasi, Katılım ve Gazeteciliğe Dair Anlayışımızı Nasıl Dönüştürebilir?" isimli makalesinde çizilen kavramsal çerçeveye dayanmaktadır. Bu makalede, veri gazeteciliğinin yönetimlerin hesap sorulabilirliğini arttırma, kurumları şeffaflaşmaları yönünde baskılama, yurttaşların enformasyon üretimine katılımını güçlendirme gibi boyutlarıla, hem toplumsal hem de mesleki süreçleri demokratikleştirme yönünde potansiyel taşıdığına vurgu yapılmaktadır. Mevcut çalışma, bu varsayımların Türkiye bağlamında ne kadar geçerliliği olduğu sorusuna cevap üretmeyi amaçlamaktadır.

\section{AMAÇ VE YÖNTEM}

Bu araştırma Türkiye örnekleminde araştırmacı veri gazeteciliğinin nasıl uygulandığını ortaya koymayı ve bu pratiğin toplumsal ve mesleki süreçleri demokratikleştirme potansiyelini tartışmayı amaçlamaktadır. Araştırma kapsamında “haber merkezlerinde veri gazeteciliğinin yeri nedir?," "uygulamada karşılaşılan sorunlar nelerdir?" ve "veri gazeteciliğinin toplumsal ve mesleki süreçlerin demokratikleşmesine katkısı nedir?" sorularına yanıt aranmaktadır. Literatürde veri gazeteciliğinin demokrasi ile bağlantısının genellikle ifade özgürlüğü, şeffaflık, hesap sorabilirlik, katılımcılık, etkileşimlilik ve eşitlik özellikleri üzerinden kurulduğu (Erkmen, 2018) görülmektedir. Bu sürece dâhil olan kişilerden de çoklu ortama hâkim ve içeriği farklı kaynaklardan derleyerek zenginleştirebilecek ve toplulukları haber süreçlerine dâhil edebilecek yetkinlikte (Doğu, 2015) dijital bekçi köpekleri olarak hesap soran bir gazetecilik pratiği icra etmeleri (Felle, 2016) beklenmektedir. Bu bağlamda çalışmada ayrıca veri gazeteciliği yapanların kimler olduğu ve bu kişilerin veri gazeteciliğini nasıl algıladıkları; veri projesi üretim sürecinde, haber merkezi içinde ve dışında sürecin nasıl ilerlediği ve karşılaşılan sorunların neler olduğu; veri projelerinde ele alınan konuların ve bunların toplumda yarattığı etkilerin neler olduğu; hikâyelerin hangi kaynaklara dayandırıldığı ve nasıl anlatıldığı, veri projelerinin okuyucu/izleyici kitlesinin kimler olduğu ve bunların haber süreçlerine dâhil olup olmadıkları alt soruları da yanıtlanmaya çalışılış̧tır.

Araştırma kapsamında veri gazeteciliğinin Türkiye örnekleminde toplumsal ve 
mesleki süreçleri demokratikleştirme potansiyelini irdelemek üzere, betimsel araştırma yöntemi kapsamında derinlemesine görüşme ve içerik analizi teknikleri bir arada kullanılmıştır. Bu doğrultuda veri haberi/projesi üretimine dâhil olmuş gazetecilerle derinlemesine görüşmeler yapılmış, ayrıca yayınlanmış veri gazeteciliği projelerinin içerik ve teknik özellikleri incelenmiştir.

Derinlemesine görüşmeler, veri gazeteciliğinin farklı ülkelerdeki uygulamasına dair vaka analizlerinde sık kullanılan bir tekniktir (Borges-Rey, 2016; Paraise, \& Dagiral, 2012; Rodriguez, 2015). Derinlemesine görüşme katılımcıların belirli konular hakkında, bazen kendilerinin bile bilincinde olmadıkları düşünce, tutum ve davranışlarını anlamaya odaklanır. Katılımcıların araştırılan konu hakkında neler düşündükleri, nasıl hissettikleri veya yaptıkları şeyleri neden yaptıkları gibi kişisel deneyimleriyle ilgilenir (Berger, 1998, p. 55). Bu doğrultuda araştırma kapsamında Türkiye örnekleminde veri gazeteciliğinin kimler tarafından nasıl yapıldığı, uygulamada hangi sorunlarla karşılaşıldığı ve demokratik süreçlere olası katkılarına dair soruların cevapları, gelişmekte olan veri gazeteciliği pratiğine haber üretmek veya editoryal süreçlere dâhil olmak yoluyla katkı sunan kişilerle yarı yapılandırılmış derinlemesine görüşmeler yapılarak aranmıştır.

Katılımcıların seçiminde veri gazetecileriyle yapılan derinlemesine görüşmelere dayanan pek çok vaka analizi çalışmasında olduğu gibi (Boyles, \& Meyer, 2016; Karlsen, \& Stevelin, 2014) kartopu örneklem tekniği kullanılmıştır. Kartopu örneklem özellikle ulaşılması zor popülasyonlarla ilgilenen araştırmacılar için, çalışma kapsamında gerekli olan belirli özelliklere sahip katılımcılara ulaşmak açısından elverişlidir. Araştırmacının yakından bildiği, dâhil olduğu bir alanda veya konuda, ilgili faaliyetlerde aktif olan kişilere güvenilir erişimi olduğu durumlar, kartopu örneklemi oluşturmak için idealdir (Lune, \& Berg, 2017, p. 39). Ancak bunun mümkün olmadığı durumlarda araştırmacının belirlediği örneklem çerçevesinden aradığı özellikleri karşılayan bir veya birkaç kişiye ulaşması da, kartopu örneklemi başlatmak için yeterlidir. Bu doğrultuda çalışmanın örneklemi oluşturulurken iki örneklem çerçevesinden faydalanılmıştır. Türkiye'de düzenli olarak veri haberi üreten medya kuruluşu bulunmadığından, dünya genelinde üretilmiş projeler için önemli bir veri tabanı teşkil eden GEN veri gazeteciliği ödüllerine Türkiye'den yapılan başvurular ilk çerçeveyi oluşturmaktadır. Bu doğrultuda ödüllere başvuran projelerin başvuru sahipleriyle iletişime geçilmiştir. Bunun yanında veri gazeteciliği eğitimleri düzenleyen ve bu eğitimlerin çıktısı olarak veri projeleri yayınlayan gazetecilik kuruluşlarından eğitim alan kişiler ise ikinci çerçeveyi teşkil etmektedir. Bunlardan biri olan, Dokuz8 Haber yurttaş gazetecilik platformu ${ }^{1}$ ile irtibata geçilerek eğitimlere katılan 
ve veri haberleri yayınlanmış profesyonel ve yurttaş gazetecilerin listesi temin edilmiş ve bu yolla da katılımcılara ulaşılmıştır. Her iki yolla ulaşılan katılımcılardan da ayrıca veri haberi yaptıklarını bildikleri kişiler önermeleri istenerek katıımcı listesi genişletilmiştir. Süreç katılımcıların sorulara verdikleri cevaplarda ve katıımcı olarak önerdiği isimlerde doygunluğa (Strauss, \& Corbin, 2014) ulaşılana kadar sürdürülmüştür. Bu şekilde veri haberi yayınlanmış (profesyonel veya yurttaş) gazetecilerle ve veri haberi üreten kurumlardaki editörler gibi farklı aşamalarda veri projelerine dâhil olmuş sekiz kişiyle görüşmeler gerçekleştirilmiştir. Katılımcıların beşi basılı ve çevrimiçi medya çalışanlarından oluşmaktadır. Geri kalan üçü ise bağımsız veya 'freelance' (serbest) veri işleri üretmiş kişilerdir. Ana akıma dâhil edilebilecek kurumlarda çalışan gazeteci sayısı sadece iki kişi iken, diğer katılımcılar küçük ölçekli ve alternatif medya çalışanlarıdır. Bu nedenle, çalıştıkları kurumların ve yaptıkları haberlerin niteliği sebebiyle risk altında oldukları gerekçesiyle isimlerinin açık olarak kullanılmamasını talep etmişlerdir. Bu doğrultuda isimleri ve çalıştıkları kurumlar belirtilmese de, kişisel bilgilerini içeren katılımcı listesi Tablo 1'de aktarılmaktadır.

Görüşmeler, beş ana temada toplanmış açık uçlu sorulardan oluşmuştur. Güncel veri gazeteciliği literatüründen (Boyles, \& Meyer, 2016; Doğu, 2015; Erkmen, 2018; Felle, 2016) ve günümüz veri gazeteciliği pratiklerinden yola çıkarak oluşturulan bu temalar veri gazeteciliğine dair altyapı, beceri, süreç ve etkileşim aşamalarını irdelemektedir. Ayrıca yarı yapılandırılmış görüşme tasarımı ve açık uçlu sorular da, katılımcıların tartışılan temaya dair farklı perspektiflerini anlamak için elverişlidir (Karlsen, \& Stavelin, 2014). Kullanılan görüşme kılavuzu Tablo 2'de paylaşılmıştır. Görüşmeler Ağustos 2018Ekim 2018 arası ile Ocak 2020 tarihlerinde, yüz yüze veya Skype araması şeklinde gerçekleştirilmiştir ve 30-80 dakika arası sürmüştür. Her bir görüşmenin sesi kaydı deşifre edilirken, katılımcıların ifadeleri temalara göre sınıflandırılarak özetlenmiştir.

Araştırmanın ikinci kısmını, üretilmiş veri gazeteciliği projelerinin içerik analizi oluşturmaktadır. Veri gazeteciliği üzerine yapılan çalışmalarda içerik analizinden hem veri toplama hem de analiz tekniği olarak sıklıkla yararlanılmaktadır (Baack, 2015; Knight, 2015; Loosen, Reimer, \& Schmidt, 2015; Stalph, \& Borges-Rey, 2018; Tandoc, \& Oh, 2017; Young, Hermida, \& Fulda, 2018; Zamith, 2019). İçerik analizi, belirli bir iletişim içeriğinde (metinde) kullanılan kalıpları, temaları, varsayımları ve anlamları belirleme çabasıyla gerçekleştirilen, aynı zamanda toplumdaki eğilimleri yansıtabilecek uzun dönemlere yayılan işlem ve süreçleri anlamlandırmaya da yarayan dikkatli, ayrıntılı, sistematik bir incelemedir (Lune, \& Berg, 2017, p. 182). Metindeki öğelerin sayılması şeklinde 
gerçekleştirilen içerik analizi, daha çok kodlanan verilerin tanımlanması ve düzenlenmesi için bir araç sağlamakta ve araştırmacının verileri temel düzeyde açıklamasına yaramaktadır. Sayım işlemi ayrıca daha ileri düzeyde yorumlayıcı analizler için bir ilk adım da teşkil etmektedir. Bu verilere dayandırılarak düzenlenen yorumlayıcı içerik analiz ise araştırmacının, metin yazarlarının sosyal dünyayı nasıl gördükleri ile bu görüşlerin daha geniş bir çerçevede sosyal bilimlerin aynı konudaki yorumlarıly ne kadar tutarlı olduklarını anlamasına yardımcı olur (p. 186).

Daha önce de değinildiği gibi düzenli olarak veri haberi üreten medya kuruluşu bulunmadığından, içerik analizinin evreni GEN veri gazeteciliği ödüllerine yapılan başvurular temel alınarak belirlenmiştir. Buna göre çalışmanın evrenini ödüllerin verilmeye başlandığı 2013 yılından günümüze kadar Türkiye'den ödüllere başvuran yedi² proje oluşturmaktadır. Bu projelerden biri Arapça olduğundan, diğer ikisi de web sitesi kategorisinden başvurmuş olduklarından örneklem dışında bırakılmışır. Bu şekilde amaçlı olarak oluşturulan örneklem, dört veri gazeteciliği projesini içermektedir. Amaçlı örneklem, araştırmacıların inceleyecekleri grup hakkında bilgi veya uzmanlığa sahip oldukları durumlarda, bu grubun belirli özelliklerini gösterdiklerini bildikleri örneklerle çalışmalarını sağlamaktadır. Bulgularının genellenebilir olması noktasındaki sınırlıı̆̆ına rağmen, amaçlı örneklem konunun özüne dair zengin veriler sunabilme özelliğinden ötürü araştırmacılar tarafından sıklıkla tercih edilmektedir (Lune, \& Berg, 2017, p. 39).

Örnekleme dâhil edilen projeler Dağ Medya tarafından hazırlanan Türkiye'deki İşçi Ölümleri Açık Veri Tabanı, gazeteci Ceyda Ulukaya tarafından yürütülen kadincinayetleri. org - Türkiye'de Medyaya Yansıyan Kadın Cinayetlerinin Haritalanması çalısması, Alp Toker'in Turkey Blocks adındaki Türkiye'deki Kitlesel Sansür Vakalarının Takip projesi ile yine Dağ Medya'dan Pınar Dağ ve Sadettin Demirel'in Türkiye'de İmam Hatip Liselerinin son 10 yıldaki durumu başlıklı projelerdir (Tablo 3). İ̧erik analizi öncelikle başvurularda proje sahiplerinin yaptıkları beyanlardan (Global Editors Network, nd); daha sonra da bu başvurularda belirtilen proje web sitelerinde yer alan haber içeriklerinden yola çıkarak gerçekleştirilmiştir. Tablo 4'te görülen kategorilerden haberin konusu, veri kaynakları ve veri setlerinin açık olarak paylaşılıp paylaşılmadığı maddeleri, araştırmacının kendisi tarafından yapılan haber analizinde de başvurularda belirtilenlerle tutarlı bulgular ortaya koymuştur. Diğer kategoriler olan haberin amacı ve haberde kullanılan veri araçlarındaki bulgular ise başvuru sahiplerinin beyanlarının doğru olduğu varsayımına dayandırılmıştır. Analizin yapıldığı Aralık 2019 tarihinde başvurularda geçen www. dagmedya.net isimli web sitesi ulaşılabilir olmadığı için, incelenen veri projelerinden 
Iş̧̧̧i Ölümleri Veritabanı'na Wayback Machine ${ }^{3}$ vasıtasıyla ulaşıımıştır. Veritabanının http://madencilik.dagmedya.net/ adresinin son kopyası olan 22 Ağustos 2017 23:32:42 tarihli kopyası değerlendirmeye alınmıştır. "Imam Hatiplerin son 10 yılı" haberinin https:// dagmedya.net/imamhatipliseleri/ olan adresinin ise arşivde herhangi bir kopyası bulunamadığından, Bağımsız Gazetecilik Platformu web sitesinde başvuru sahipleri tarafından yazılan araştırma (haber) özeti (Dağ, \& Demirel, 2016) dikkate alınmıştır.

Örneklem yukarıda anılan literatürden ve GEN web sitesinde yarışma başvuru formlarındaki kategorilerden yola çıkarak oluşturulan farklı kategorilerde incelenmiştir. Buna göre incelenen veri projeleri içerik açısından konuları ve veri kaynaklarına göre; şekil açısından haber hikâyelerinde yer alan görsel/teknik unsurlara göre (tablo, harita, grafik, zaman çizelgesi, infografik, veri tabanları, fotoğraf, video, interaktif arama vb.) ve kullandıkları veri işleme teknolojilerine göre kodlanmıştır. İçerik analiziyle elde edilen bulgular, derinlemesine görüşme katılımcılarının beyanları ve literatürdeki tanımlamalarla karşılaştırmalı olarak değerlendirilmiştir. Çalışmanın örneklemi oldukça küçük olduğundan ve incelenen kategorilerde içerikler arasında pek çok farklılık bulunduğundan, nicel araştırmadan farklı olarak bulguların yüzdelik istatistikler ile ifade edilmesi yerine, yorumlanması ve özetlenmesiyle yetinilmiştir (Vanderstoep, \& Johnston, 2009, p.7).

\section{BULGULAR}

\section{Veri Gazetecileri ve Çalışma Koşulları}

İçerik analizi ve derinlemesine görüşme bulguları Türkiye örnekleminde veri haberlerinin genellikle çevrimiçi ve alternatif medya kuruluşlarında, küçük ölçekli haber merkezlerinde ve küçük çalışma grupları tarafından üretildiğini göstermektedir. İçerik analizine dâhil edilen altı başvurudan beşinde haber merkezi/ekip büyüklüğü başvuru sahipleri tarafından "küçük" olarak belirtilmiş, birindeyse hiçbir şey belirtilmemiştir (Tablo 3).

Katılımcılardan yalnızca biri (K3), üyesi olduğu International Consortium of Investigative Journalists (ICIJ) vasıtasıyla uluslararası bir veri projesi içinde çalışmayı deneyimlemiştir. Yine de bu gazeteci bile, kendi çalıştığı kurumda haberi çok büyük ölçüde tek başına takip etmesi gerektiğini, meslektaşlarından çok kısıtlı destek alabildiğini belirtmiştir. Rogers bu şekilde tek başına çalışan veri habercilerini "yalnız kovboy" (lone ranger) olarak nitelemektedir (Rogers, 2013). Gerçekten de görüşme bulguları, Türkiye örnekleminde veri haberi yapmaya gayret eden kişilerin çoğu zaman bu işin üstesinden 
tek başlarına kalkması beklendiğini ortaya koymaktadır. Ekip çalışmalarındaysa, çalışma grupları en fazla 2-3 kişiden oluşmakta, görev dağılımı veriyi toplayan/araştırmacı, haber hikâyesini yazan ve görevi hikâyeyi görselleştirmek olan bir tasarımcı/yazılımcı şeklinde gerçekleşmektedir (K2, K3, K5, K6, K7).

Bunun yanında zaman zaman, telif karşılığı veya sosyal sorumluluk anlayışıyla veri haberleri üreten bağımsız araştırmacılar da bulunmaktadır. Örneğin her ikisi de ana akımda çalışmakta olan K2 ve K6 (Tablo 1), sosyal sorumluluk amacıyla kendi "dert edindikleri" meselelere dair veri setlerinin görselleştirmelerini içeren bağımsız ve bedelsiz veri projelerini hayata geçirirken;'freelance' çalışan K8 de muhabirlik faaliyetlerinin bir parçası olarak telifli veri haberi de ürettiğini belirtmiştir.

Genel olarak gazetecilerin veri haberi yapabilmek için gereken medya okuryazarlığı ve dijital okuryazarlık becerilerinin eksik olduğunu söylemek mümkündür. Katılımcılardan dördü, veriyi okumak noktasında yetkin olduklarını düşünseler bile, onu analiz edip görselleştirmek konularında yeterli donanımları olmadığını ifade etmiştir (K2, K3, K6, K8). Ayrıca K2 veri haberlerini hazırlarken meslektaşlarından teknik yardım alamadıklarını, geleneksel medyada çalışan pek çok gazetecinin bu tarz bir metodolojik çalışma disiplininden yoksun olduğunu düşündüğünü belirtmiştir. K2 gibi K7 de, veri haberi yaparken destek alınacak kadar sayısal becerilerine güvenilir gazetecilerin çok sınırlı olduğunu belirtmiştir. K6 ve K4 ise bu yetersizlikleri eğitim sistemiyle bağlantılandırarak, temel sayısal kavrama, düşünme (K6) ve veri okuryazalığı (K4) eksikliğine yormaktadır. Siyasal Bilimler alanında lisans derecesi olan, gazeteciliği lisans stajı için girdiği ana akımdaki gazetenin dış haberler servisinde öğrendiğini belirten K4, genel eğitim sistemine dair eksikliklerin yanında durumu ayrıca ülkedeki gazetecilik eğitimiyle de bağlantılandırmaktadır:

Gazeteciliği Türkiye'de İletişim Fakülteleri'nden çok iyi öğrenip gelen sayısı azdır, çoğunlukla gazetede öğrenilir. Kuşaktan kuşağa bilginin aktarımı çok önemlidir. Ama veri gazeteciliği söz konusu olduğunda, bu mümkün değil. Öyle bir bilgi birikimi yok. Veriyle çalışmak çok eski bir pratik olsa da, bugünkü anlamıyla dijital araçları kullanarak o geçişi sağlayacak, bilip de aktaracak birileri yok. İletişim fakültelerinde bu konudaki eğitim çoğu okulda yetersiz.

Keza K7 de dijitalleşme nedeniyle eskiye nazaran çok fazla veri üretildiğini, temel bir veri okuryazarlığı bilgisinin bunu işleyerek yeni hikâyeler anlatmak için yeterli 
olduğunu belirttikten sonra, mevcut gazetecilik eğitiminin buna olanak vermediğini belirtmektedir:

Veriyle iş yapmak çok da zor bir şey değil aslında ama gazeteciler genellikle sözel bölümlerden oldukları için, veriye hiç meyletmedikleri için, bir 'excel sheet' ile düşünemedikleri için çok zorlanıyorlar. Okullar da tabiatı gereği yavaş bir kurum olduğundan dijitalleşmenin gereklerine hızlıca adapte olamıyor.

Gazetecilerin meslek içi eğitim imkânları sorgulandığında, daha önce de ifade edildiği gibi kurumların veri gazeteciliğinin önemini kavramamış ve buna ilgi göstermiyor olmasının, personellerine bu konuda meslek içi eğitim sunmalarının önündeki en büyük engel olduğu anlaşılmaktadır. Bununla birlikte K2, ana akımdaki zaman baskısının ve iş yükünün, veri gazeteciliği konusundaki eğitimleri kendi kendine dahi olsa takip edememesine neden olduğunu belirtmiştir. K4'ün ise bu konuya tam aksi yönde bir bakışı vardır:

Özellikle kağıt gazete tarafında çalışan gazeteciler az ve yavaş çalışmaya alışmışlar. Haftada birden daha düşüktür çoğunun imzalı haber ortalaması. 10 kişilik bir ekipse 3-4 kişi çok çalışır, böyle bir verimsizlik ve dengesizlik vardır hep. Bölümün başındakinin iş yükünü doğru dağıtıp verimli hale getirmesi önemli. Hal böyleyken yine de çoğu kişi yeni bir şeyler öğrenmeye geldiğinde iş yükünü bahane eder. Veride de aynı durum geçerli.

Alternatif medyaya bakıldığındaysa, ekonomik sıkıntıların veri işlerinin gelişmesinin önündeki en önemli engel olduğu görülmektedir. Kendisi de alternatif bir haber platformunda yönetsel pozisyonda çalışan K1 bunu şu şekilde ifade etmektedir:"Zaten alternatif medyada günü çevirme telaşı var, ülkedeki durumdan ötürü reklam alamıyorlar. Gelirleri ya fonlara bağlı, ya da kişisel bağışlara. Bu durumdayken bir de çalışanı eğitime göndermek noktasına hiç gelemiyorlar." Katılımcı ayrıca, kurum içi ve dışından muhabirlere yönelik veri eğitimleri düzenleyen bu haber platformu için de, bu eğitimlerin ancak uluslararası bir fon alınması yoluyla mümkün olduğunu belirtmiştir.

Veri okuryazarlığı ve eğitim kısıtlarını aşıp veri haberine başlayabilenler için ise, editörlerin işin gereklerine yönelik yaklaşımı zorlayıcı olmaktadır. Örneğin K5, "bir veri haberi çalışması tam odaklanma ve adanmışlık ile uzun süreli (bazen aylarca) çalışmayı gerektirse de, editörlerin gazetecilere veri haberi yayın aşamasına gelene kadar başka görevler vermek suretiyle işin takibini zorlaştırdığını" ifade etmektedir. 
Katılımcılar arasında ana akım medyada veri haberleri yayınlanan sadece K4 bulunmaktadır. Kendisi de bu projenin yayınlanması ile ilgili süreci anlatırken “O dönem Architera'da iki mimarın yaptığı güzel bir işi, daha büyük bir okuyucuya ulaştırmak için kendileriyle irtibata geçtim. İkisi de veriyle çalışabilen, ama aynı zamanda yaratıcı bakabilen, veri setine ilgi çekici sorular sorabilen, gazetecilik bakış açısına sahip kişilerdi. 5-6 işten oluşan bir seri yayınladık, hatta görselleştirmeyi de kendileri yapabildiler. Ama sistematize edemedik" şeklinde aktarmaktadır. Nitekim katılımcı aynı dönemde çalıştığı gazetede veri birimi kurma yönünde çabaları olmuşsa da o konuya kaynak ayrılmadığı için kendi inisiyatifiyle hayata geçirdiği bu tarz işlerden öteye gidemediklerini belirtmiştir. Ana akımda bu işin neden yapılamadığı sorgulandığında K1, K2 ve K3 mülkiyet, zaman baskısı ile eski tip okuyucu/izleyici algısı ve gazetecilik anlayışının etkili olabileceğine dair düşüncelerini paylaşmışlardır. Mesela K2, ana akım medyada çalışmasına rağmen, buradaki profesyonel faaliyeti dâhilinde değil, bağımsız olarak bir veri projesi üretme imkânı bulduğunu belirtmiştir. Kendi deneyiminden hareketle, ana akımda genellikle "genç işi, yeni bir tür gazetecilik" olarak görülen veri gazeteciliğinin önemi kavranamadığı için, buralarda çalışan gazetecilerin de ancak günlük rutinlerinden zaman bulabilirlerse, tamamen kendi merak ve çabaları ile veri haberi yapmalarının mümkün olabildiğini iddia etmektedir.

Bu çalışma koşullarında veri gazeteciliğinin daha ziyade yeni mezunlar, işsiz/işten çıkarılmış veya 'freelance' gazeteciler için telif karşılığı yapılabilecek bir fırsat olarak görüldüğü ve bu kiş̧ilerin veri gazeteciliği konusunda kendilerini geliştirmek noktasında daha istekli oldukları anlaşılmaktadır. Ancak bu kesimler için de eğitim ve araştırma süreçlerinin fonlanması meselesi, çözülmesi gereken önemli bir engel teşkil etmektedir. Türkiye Gazeteciler Sendikası (TGS) Akademi, Açık Veri ve Veri Gazeteciliği Derneği, Newslab Turkey, Veri Okuryazarlığı Derneği, Dokuz8 Haber, Journo vb. kuruluşlar, gazetecilere yönelik ücretsiz eğitim ve atölye çalışmaları düzenlemektedir. Bu etkinliklerin büyük kısmının finansmanı uluslararası fonlarla karşılanmaktadır. Mesela Dokuz8 Haber tarafından düzenlenen veri eğitimine katılan K8, şehir dışından katıldığı bu etkinliğe ancak eğitimin ücretsiz olması ve konaklamanın da platform tarafından karşılanması sayesinde katılabildiğini belirtmiştir.

Türkçe dilinde ücretsiz çevrimiçi eğitimlerin azlığı, veri gazeteciliği pratiğini yabancı dil bilen bir azınlığın öğrenebileceği bir işe indirgemektedir. Katılımcıların tamamı orta veya iyi düzeyde İngilizce bildiklerini belirtmiştir. Ancak bunlardan sadece K2, K4, K5 ve K7; Coursera, Learno gibi platformların sunduğu çevrimiçi açık kitlesel derslerden 
haberdar olduklarını ve faydalandıklarını belirtmişlerdir. Bu nedenle yabancı literatürü düzenli takip ederek Türkçeleştiren http://www.verigazeteciligi.com/ gibi girişimlerin çoğaltılması, daha fazla sayıda kurum ve gazetecinin veri gazeteciliğinden haberdar olması açısından önemlidir. Nitekim Aralık 2019'da Newslab Turkey ve Veri Okuryazarlığı Derneği işbirliğiyle yayınlanan, 17 bölümlük çevrimiçi Temel Veri Gazeteciliği Eğitimi de önemli bir kaynaktır.

\section{Veri Haberlerinin Teknik ve İçerik Özellikleri}

Veri haberlerine dair analiz, Türkiye örnekleminde konuya daha çok hak odaklı bir perspektifle yaklaşıldığını göstermektedir. Mevcut işlerin konularının ağırlıkla toplumsal cinsiyet eşitsizlikleri, insan hakkı ihlalleri, basın ve ifade özgürlüğü, şiddet ve ölüm içeren olaylara odaklandığı anlaşılmaktadır. Nitekim veri gazeteciliği ödüllerine web sitesi kategorisinden başvurmamış olan dört aday araştırma/veri projesi de Türkiye'deki işçi ölümlerini, kadın cinayetlerini, kitlesel sansür uygulamalarını ve eğitim hakkı tartışmaları bağlamında İmam Hatip Liseleri'ni ele almaktadır (Bkz. Tablo 3). Bunun yanında seçimler, ekonomi ve spor da veriye dayalı haberlerin görüldüğü alanlardır ancak bu haberlerde verinin daha çok görselleştirmeler yoluyla haber hikâyesini destekleyici biçimde kullanıldığı belirtilmektedir (K3, K8). Ayrıca sınırlı da olsa sızıntılara dayandırılan araştırmacı veri haberlerinden bahsetmek de mümkündür. Cumhuriyet gazetesinin 2016-2018 yılları arasında yaptığı “Panama” ve "Paradise Papers" haberleri buna örnek gösterilebilir.

Ne var ki konulardan yola çıkarak yapılanın "hesap soran bir gazetecilik pratiği" (accountability journalism) ${ }^{4}$ olduğunu söylemek mümkün gözükmemektedir. Bunun ilk nedeni katıımcıların genellikle daha yayınlanabilir olduğunu düşündükleri konulara yönelmek zorunluluğundan bahsediyor oluşları, ikinci nedeni ise haber hikâyelerinin uzun süreli takibinin yapılmıyor oluşudur:

Gazetede çalışırken haber konusunu her zaman önemine göre seçemiyoruz. Editörlere daha yayınlanabilir gelen belli bazı konular var, takip edeceğimiz hikâyeyi seçerken ister istemez bunları dikkate almak ve satılacak haberlere yönlenmek zorunda kalabiliyoruz (K6).

Günlük tempo içinde editörler sürekli yeni işlerle geldikleri için, elimizdeki hikâyenin uzun süreli takibini yapmak zor. Ancak bazen dosya haber şeklinde işler yapmak mümkün olabiliyor (K5). 
Zaten katılımcıların veri haberleri vasıtasıyla demokratik tartışmayı canlandırmak gibi bir rolleri olduğuna dair de güçlü bir algısı bulunmamaktadır. Yine de haberlerde kamu yararının gözetildiği söylenebilir. Yapılan işi aslen, veriyi önden temizleyip tasnif ettikten sonra içinden kamu yararına görülen kısımların alınıp haberleştirilmesi olarak nitelemek mümkündür (K1, K5). Bu süreçte veri de içinden büyük haber hikâyeleri çıkarılacak bir kaynaktan çok, mevcut haber hikâyelerini "süsleyecek" bir unsur olarak ele alınmaktadır. Bunun yanında K2, K5, K6, K7 veri aracılığıyla hikâyelerin tekil vakalar olmadığını daha etkili biçimde ortaya koyabildikleri için veri kullanımını cazip bulduklarını belirtmiştir. Bu nedenlerle veri haberleri genellikle görselleştirmelerle sınırlı kalmakta, verinin yorumlanmasına yönelik daha derinlikli araştırmacı gazetecilik pratiklerine ise sık rastlanmamaktadır.

Veri gazeteciliği ödüllerine başvuran projelerin analiz bulguları da katılımcıların beyanlarını doğrular niteliktedir. Projelerde kullanılan veri araçlarına bakıldığında, araştırmacı gazetecilerin sıklıkla kullandıkları temel veri araçlarından (Kubzansky, 2018) daha çok veri toplama, düzenleme, kazıma ve temizleme (Excel, Google Spreadseets, Open Refine, Tabula) ile görselleştirmeye yönelik (datawrapper, Google Maps, Tableau) olanların kullanıldıkları görülmektedir. Bunlarla birlikte ayrıca Influx DB, Fusion Tables ve SQL gibi veritabanı yöntemiyle ilgili araçlar ile farklı kodlama araçlarından da faydalanılmıştır. İncelenen projelerin hepsi değişen oranlarda görsel/teknik unsurlar içermektedir (Tablo 4). Bunları en yoğun biçimde kullanan, yine diğerlerine göre daha çok boyutlu bir araştırma çalışmasının da ürünü olan İmam Hatip Liseleri projesidir. Projede konunun ele alınmış olan her bir boyutu için harita, tablo, zaman çizelgesi gibi farklı görselleştirme tekniklerine başvurulmuştur. Haritalama bütün projelerde kullanılmış olan tek görselleştirme tekniğidir. Bu sayede vakaların münferit olmadıklarını vurgulamak ve hangi bölgelerde yoğunlaştıklarını net bir şekilde ortaya koymak mümkün olmaktadır.

\section{Veri Haberlerinin Okuyucu/İzleyici Kitlesi}

Katılımcılara haberlerinin okuyucu/izleyici kitlesi ile ilgili sorular sorulduğunda, K1, K5, K6 yasama süreçleriyle ilgilenen kişilerden oluştuklarına dair algılarından bahsetmişlerdir. Bununla ilgili herhangi bir kayıt çalışması yapmadıklarını belirtmekle birlikte, sosyal medya paylaşımları ve haberlerine yapılan geri bildirimleri değerlendirdiklerinde, haberlerini takip eden kesimler arasında muhalefet milletvekillerini, diğer gazetecileri, akademisyen ve araştırmacıları, öğrencileri ve haberlerine konu teşkil eden alanda faaliyet gösteren sivil toplum kuruluşlarını saymışlardır. 
Bu ifadeler de göz önünde bulundurulduğunda, veri haberlerinin etkileşim alanının eğitimli ve dijital okuryazar bir elit kesimle sınırlı kalması riskine yönelik derinlemesine sorgulamaların yapılması gerekli görünmektedir. Veri haberlerinin okuyucu/izleyici kitlesiyle ilgili, haberlerin etkileşim oranları ve kamuoyu yaratıp yaratamadığı konularında herhangi bir sistematik veri kaydının veya akademik araştırmanın bulunmayışı; veri gazeteciliğinin demokratikleştirici potansiyelini gerçekleştirmesi üzerine yapılan tartışma ve tespitlerin sağlam bir zemine oturtulamamasına neden olmaktadır. Keza Doğu da (2015), veri okuryazarlığının tam olarak gelişmemiş olduğu bir ortamda, gazetecilerin eşik bekçisi rolünü pekiştirme riskine dikkat çekmektedir.

\section{Veri Gazeteciliğinin Demokratikleştirici Potansiyeli}

Veri gazeteciliğiyle demokrasinin ilişkisini dört temel boyutta incelemek mümkündür: Açık veri, şeffafık ve hesap sorulabilirlik, nesnellik ve gazeteci özerkliği ile katılım ve etkileşim (Erkmen, 2018). Katılımcılara bu boyutlarla ilgili sorular yönlendirilmiş, hem sürecin nasıl işlediği hem de yaptıkları veri haberleriyle bu boyutlara katkı sunmak noktasındaki rollerine dair algıları anlaşılmaya çalışılmıştır.

\section{Açık Veri}

Türkiye'de açık verinin durumunu değerlendirmeleri istendiğinde, katılımcıların beşi resmi kaynaklara bağımlı olduklarından yakınmaktadır. Bu bulgu, Narin vd.'nin (2017) çalışmalarında dikkat çektikleri veri gazeteciliğinin gelişimi önündeki engellerle de tutarlıdır. Bu devlet kurumları haricinde sistematik biçimde veri üreten başka kaynak olmamasına dayandırılmaktadır (K1, K2, K6, K7, K8). Başat veri kaynağı olan Türkiye İstatistik Kurumu'nun (TÜiK) metodolojisi ise son yıllarda sıklıkla eleştirilmekte, kurumun ürettiği verilerin manipüle edildiği tartışılmaktadır (Aktan, 2018). K1 ayrıca "açık verinin çoğu zaman düzenli ve süreklilik arz edecek şekilde ve tutarlı bir metodolojiyle üretilmiyor" olduğunu belirtmektedir. Bu da bir araştırma haberinde zamana bağlı karşılaştırmalar yapmayı veya değişkenler arasındaki ilişkileri ortaya koymayı hemen hemen imkânsız kılmaktadır.

Bilgi Edinme Hakkı konusu da gazetecilerin sıkıntı yaşadıkları bir noktadır. Katıımcılar ulaşmak istedikleri verilerin, ilgili kurumlarca ya hiç toplanmadığını, ya da toplansa bile paylaşılmadığını belirtmektedir. Başvuruların bekleme süresinin uzunluğu ve kurumların talepleri kendilerinin yetki alanında olmadığı gerekçesiyle geri çevirme 
eğiliminde oluşu da dile getirilen sıkıntılardır (K2, K3, K5, K6, K7, K8). Buna göre Bilgi Edinme Hakkı başvurularının genellikle kurumdan kuruma aktarıırken ya zaman ya da sabır yetersizliğinden işlevsiz hale geldikleri anlaşılmaktadır. Olumlu sonuçlanan başvurularda elde edilen verinin kalitesine değinecek olursak; çoğu zaman zaten kamuya açık olan verilerin tekrar paylaşıldığı, paylaşılan verilerin makine okunabilir formatlarda veya güncel olmadığı ifade edilmektedir (K1, K4, K5, K7). Nitekim veri gazeteciliği ödüllerine başvuran projelerin analiz bulguları da incelenen çalışmaların üçünde Bilgi Edinme Hakkı başvurusu yapıldığını, birinde herhangi bir sonuç alınamazken diğer ikisinde de kapsamlı yanıtlara ulaşılamadığını ortaya koymaktadır (Tablo 4). K7 konunun bir diğer aksayan boyutunun, bu kurumların denetlenemeyişi olduğunu vurgulamakta ve bunu güncel bir örnekle açıklamaktadır: "Bazen de veri talep ettiğinizde, bir süre sonra kendisini gizlemeye çalışıyor. Mesela Kanal İstanbul etrafında kimlerin emlak sahibi olduğu bilgisi haberleştirilince, hemen üzeri örtüldü. Artık Sayıştay da işlevsel değil zaten".

Bu noktada Türkiye açık veri ekosistemine yönelik olarak, paydaşlardan özel sektör ve vatandaşın katkııının zayıf olduğunu; kamu kurumlarının ise "yasal olarak açık" gözükmenin gereklerini kısmen yerine getirmekle birlikte, "teknik olarak açık" (Özkan, 2019) olmaktan kaçınarak bilgiye erişimi zorlaştırdıklarını söylemek mümkün gözükmektedir. Bu durum Howard'ın (2014) alternatif veri kaynaklarının zayıf kaldığı ortamlarda, kamu kurumları ile özel sektörde faaliyet gösteren uzmanların, kendi çıkar ve uygulamalarını destekleyecek biçimde neyin önemli olduğuna karar verebilecek, aynı yolla önemli haber hikâyelerini de detaylar arasında kaybedebilecek güce sahip olduklarına dair tespitini Türkiye bağlamında geçerli kılmaktadır.

Nitekim hükümetlerin açık devlet olma yolundaki etkinliklerini değerlendiren raporlarda da Türkiye'nin durumu olumlu değerlendirilmemektedir. Mesela Uluslararası Açık Toplum Vakfı'nın Küresel Açık Veri Endeksi 2016-2017'de Türkiye 94 ülke arasında 45. sırada (Open Knowledge International, 2016); Web Vakfı'nın 5. Açık Veri Barometresi'de (Open Data Barometer, 2017) ${ }^{5}$ ise incelenen 30 ülke arasında 26. sırada yer almıştır. Barometrenin son versiyonu öncekilerin aksine sadece Uluslararası Açık Veri Şartı veya G20 Yolsuzlukla Mücadele İçin Açık Veri IIlkeleri'ne taraf olarak açık veri konusunda taahhütte bulunan ülkeler ele alınmıştır. Bu bağlamda "Liderler" olarak adlandıılan bu grupta Türkiye, geride kalan beş sene içinde gerekli örgütsel ve altyapı değişikliklerini yapmadığı için Kosta Rika ve Şili ile birlikte "geride kalanlar" (stragglers) kategorisinde sınıflanmaktadır. 
Türkiye örnekleminde veri toplamak kadar toplanan verinin sağlamasını yapmak da zorludur. Ulusal düzeyde istikrarlı biçimde alternatif veri üreten kaynakların yetersizliğini K7 insan gücü ve finansal kaynak yetersizliğine bağlamaktadır. Yine de Doğruluk Payı, Teyit, TGS gibi kurumların çalışmalarını önemsediğini; ayrıca Cumhuriyet Halk Partili bazı belediyelerin kendi veri merkezlerini kurup verileri kendilerinin yayınlayacağına yönelik beyanları hayata geçirilirse, bunların dengeleyici olabileceğini düşündüğünü belirtmektedir.

Bu ortamda Ekonomik Iş̧birliği ve Kalkınma Örgütü (OECD), Avrupa Birliği, Dünya Bankası, Dünya Sağlık Örgütü gibi uluslararası kuruluşlar, güvenilir kaynaklar ve teyit referansları olarak tercih edilmektedir (K3, K6, K7, K8). Ancak bu kurumların verileri kendilerinin bağımsız olarak mı topladığı yoksa TÜiK verilerini mi işlediği, üzerinde durulması gereken ayrı bir konudur. Açık veri ve bilgi edinme konusundaki kaynak sorununun önüne geçilebilmesinin yolu, sivil toplum kuruluşları, sendika ve meslek örgütlerinin kendi çalışma alanlarıyla ilgili zaman zaman ürettikleri istatistiklerin, düzenli şekilde ve birer veri tabanı oluşturacak biçimde üretilmesinden geçmektedir. Bununla birlikte gönüllü yurttaş katılımcılığına dayanan Doğruluk Payı, Mülksüzleştirme Ağları, Oy ve Ötesi, Teyit ve Veri Kaynağı gibi girişimlerin de desteklenip geliştirilmesinde fayda vardır.

\section{Şeffaflık ve Hesap Sorulabilirlik}

Türkiye'de siyasal sistemdeki değişiklikler ve medyadaki sahiplik yapısı, geleneksel medyanın dördüncü güç işlevini yok etmiş durumdadır. Çoğu hükümete yakın patronlar tarafından yönetilen medya gruplarının hükümet ile olan ilişkileri editoryal kadroların önündeki en büyük otosansür mekanizması olarak belirmektedir. Buna rağmen yayınlanabilen haberlere getirilen erişim engelleri de şeffaflık ve hesap sorulabilirlik konularında sıkıntılara işaret etmektedir. Mesela Cumhuriyet Gazetesi'nin Panama Belgeleri haberlerini yapan muhabir Pelin Ünker'e dava açılmasının yanı sıra, Cumhuriyet ile birlikte belgeleri haberleştiren diğer mecraların içeriklerine de erişim engellenmiştir (“Panama belgeleri...," 2016). Nitekim Freedom House'un İnternette Özgürlük 2019 raporunda Türkiye, internet özgürlüğünün en belirgin biçimde kısıtlandığı ülkelerden biri olarak nitelenmiş, haberlerin de dahil olduğu çevrimiçi içeriklere getirilen yasaklara da vurguyla ülke "özgür değil" kategorisinde sınıflandırılmıştır ("Freedom on the...," 2019). Keza Engelli Web 2018 raporunda da yıl boyunca 3.306 haber içeriğine erişimin engellendiği belirtilmektedir (Akdeniz, \& Güven, 2019). Hesap soran gazeteciliğin 
önündeki bir diğer engeli ise daha önce ana akımda, şu anda ise çevrimiçi alternatif bir haber merkezinde çalışmakta olan K4 şu şekilde ifade etmektedir:

Genel olarak katma değerli gazetecilik içerikleri Ingilizce kaynaklara kıyasla oldukça az, bunun farklı sebepleri var. Maliyetli, çok uğraştıran işler, onu finanse edebilecek fazla gazete, televizyon yok. Zaten finanse edilebilse bile iyi gazetecilik yaptığınızda karşılaşılan siyasi sorunlar, baskılar vs. var.

Bu ortamda veri haberlerinin odaklandığı nokta temel haklara yönelik ihlallerin kayıt altına alınmasından öteye gitmemektedir. Bu nedenlerle, genellikle verinin temel araçlar yardımıyla görselleştirilmesi yoluyla ihlaller görünür kılınmakta, ancak zaman ve işgücü kısıtııı̆ından dolayı haber hikâyeleri takip edilememektedir (K2, K5, K8). Veriyi analiz edip hakkında eleştirel haberler yaparak onu bir toplumsal/siyasal baskı mekanizmasına dönüştürmek şu aşamada yaygın bir amaç olarak görülmemektedir. İncelenen projelerin dördü de, insan hakları perspektifinden farklı meseleleri ele almaktadır. Ancak bunlardan sadece İmam Hatip Liseleri ile ilgili proje konuyu derinleştirerek farklı boyutlarıyla ele almakta ve 12 parçalık bir yazı dizisi olarak okuyucuya sunmaktadır. Diğer projeler de ele aldıkları meseleleri görünür kılıp çözüm önerileri geliştirmek için referans olmak gibi amaçlar taşısalar da, bunu bizzat kendileri yapmak yerine farklı kesimlere kaynak olmakla yetinmektedir (Tablo 4).

Zaten 2016'daki darbe girişimiyle ülkenin gündemi köklü bir biçimde değiştiğinden, o günlerde sürmekte olan veri projelerinin konuları -zaman zaman haberi izleyen gazetecinin kendisi tarafından bile- ikincil önemde algılanmaya başlanmıştır:

Projeyi devam ettir(e)medim, çünkü 15 Temmuz döneminde gündemi bambaşka konular meşgul etmeye başlamıştı. Kimsenin kadın cinayetleriyle ilgilenecek durumu kalmadı gibi hissettim. Zaten ben de iş yükü olarak bununla ilgilenebilecek durumda değildim (K2).

Veri haberlerinden hareketle kamuoyu yaratılıp yaratılamadığı noktasında gazetecilerin kendi haberlerine yönelik gözlemlerinin sınırlı olduğu da dikkat çekmektedir. Katılımcılardan yalnızca biri, kendi haberinden hareketle muhalefetin mecliste soru önergeleri verdiğini, ancak onların da Adalet ve Kalkınma Partisi ve Milliyetçi Hareket Partisi oylarıyla reddedildiğini belirtmiştir (K3). Bu noktada, sivil toplumun ve ilgili konularda faaliyet gösteren sivil toplum ve meslek örgütlerinin de yönetimlere hesap 
sormak ve dönüştürücü icraatlar yapmaları yönünde baskı oluşturmak konularında daha aktif olması gerekliliğinin altı çizilmektedir (K1, K6).

\section{Nesnellik ve Gazeteci Özerkliği}

Bu koşullar altında veri haberi üretebilen medya kuruluşları genellikle bağımsız, alternatif medya ve yurttaş gazetecilik inisiyatifleridir. Bu kurumlar genellikle bağış ve/ veya uluslararası fonlar ile ayakta durmaya çalışmaktadır. Devlet ve patronajla doğrudan bir çıkar ilişkisi barındırmayan bu finansman modelinin, bu kuruluşlara görece özerk bir hareket alanı yarattığını söylemek mümkündür. Gazetecilerin özerkliğini ve nesnelliğini korumasını sağlayacak bir başka finansman modeli de kitle fonlaması olarak öne çıkmaktadır. Nitekim uluslararası uygulamalara bakıldığında okuyucu kitlelerin finansman için harekete geçirildiği başarılı örnekler mevcuttur (Manuli, 2013). Katılımcıların tek tek veri haberlerini veya muhabirleri kitle fonlaması yoluyla finanse etme yönünde bazı girişimleri olmuşsa da, henüz okuyucudan bu tür bir bağlılık bulabilmiş bir yapı bulunmamaktadır. Aynı şekilde analiz edilen projelerin başvurularında da, kitle fonlamasına başvurduklarına dair herhangi bir bilgi paylaşılmamıştır. K7 kitlelerin desteğini sağlamakta sürekliliğin önemine vurgu yapmaktadır: "Insanlar işten çıkarılıyor, bir sene boş kalıyor. Bu sürede yeni şeyler yapabilirler. Ama süreklilik lazım, tek bir iş yapıp da para istenmez tabii." Katılımcı ayrıca'Fact checking' organizasyonlarının gelişim sürecinin veri gazeteciliği için de bir model sunabileceğini savunmaktadır:"Başta teyitçi diye biri yoktu, onlar kendilerini yetiştirdiler, gazetecileri istihdam ettiler, oldu. Veride süreç biraz daha zor olur, ama sonuçta olur. Teyit ve Doğruluk Payı görünür oldukları için büyüdüler. Sadece veri haberi yapan bir platform olsa, benzer şekilde o da büyür bence. Herhalde temel eksik o."

2018 yılının medya gündemine peş peşe gelen araştırmacı gazeteci cinayetleri damga vurmuştur. Bunların arasında Maltalı gazeteci Daphne Caruana Galizia ve Slovak gazeteci Jan Kuciak gibi doğrudan Panama Belgeleri üzerinde çalışan ve hükümetlerin yolsuzluklarını veya mafyayla ilişkilerini ifşa eden gazeteciler vardır ("2 journalists...," 2019). Hem güvenlikle ilgili, hem de haklarında açılan davalar gibi yasal kaygılar, gazetecilerin 'freelance' çalışmak yerine bir kurumun koruyucu çatısı altında çalışmayı tercih etmesine neden olmaktadır (K3, K8). Bu da beraberinde -alternatif medyada bile olsa- editoryal baskıları getirip gazetecinin özgürlük alanını daraltmakta, ortaya çıkan işin kalitesini etkilemektedir. Özellikle zaman baskısı ve veri haberini takip ettiği süre içinde başka haber hikâyeleri de hazırlama zorunluluğu buna örnek gösterilebilir (K3, 
K5). Bu baskılar özünde yavaş bir gazetecilik pratiği olması gereken veri gazeteciliğinin çıktılarına da yansımaktadır.

\title{
Katılım ve Etkileşim
}

Dünyada veri gazeteciliğinin temel prensiplerinden biri açıklık olarak benimsenmiş olsa da (Baack, 2011) Türkiye örnekleminde ham veri ne gazetecilerin kendi arasında ne de okuyucuyla paylaşıımamaktadır. Şeffaflığı amaçlaması ve gözetmesi beklenen gazetecilerin bile bu anlamda şeffaf olmadıkları söylenebilir. Genel uygulamanın aksine, analiz edilen projelerden Dağ Medya tarafından hazırlanan ikisinde (İşçi Ölümleri Veritabanı ile İmam Hatip Liseleri haberi) veri setlerinin ve veri görselleştirmelerine dair kullanım kılavuzlarının açık olarak paylaşılığı görülmektedir (Tablo 4).

Katılımcılardan K1, K5 ve K6 veri setlerini paylaşmıyor oluşlarını, okuyucu/izleyicinin veri okuryazarlığı anlamında eksik görülmesi ve haberi takip etmeyeceğinin düşünülmesi ile gerekçelendirmektedir. K7 ise okuyucuların sayıları sevmediğine yönelik kalıp yargıyı reddederek, sorunun sayıların haberde aktarılış biçimlerinde olduğunu belirtmektedir:

\begin{abstract}
Bir paragraf rakam yazılsa ben de sevmem. Bir iyisi tablo, tabloyu da geçtim görselleştirince asında hoşlarına gider. Onu da okuyamayacak, veri okuryazarlığı o anlamda da olmayan geniş bir kitle yok mu? Var. Ama sen de haberini illa geniş kitlelere göre yapmak zorunda değilsin. Maharet zaten onu da anlatmak.
\end{abstract}

Diğer yandan, gazetecilerin rekabetçi anlayışlarının veri haberlerinin gerektirdiği katılımcı ve dayanışmacı ruhun önünde en büyük engel olduğu anlaşılmaktadır:

\begin{abstract}
Projenin verisini medyada konuyla ilgili çıkmış haberler oluşturuyordu. Bağımsız bir haber platformunun bu konuyla ilgili yapmış olduğu çetele çalışmalarından da faydalandım. Bana destek verip, güzel bir iş olmuş demelerini beklerken, neticede onların yaptıklarına bir değer katan bir iş oldu bizimki, o veriyi göze görünür ve daha anlaşılır kıldı, biz bunu zaten yapmıştık dediler sadece (K2).
\end{abstract}

Bununla birlikte, gerçekten de çoğu zaman okuyucu/izleyicinin haber süreçlerine katıımının çok düşük olduğu anlaşıımaktadır. Katılımcıların veri toplanması aşamasında kitle kaynak kullanımı konusuna yaklaşımları sorgulandığında, birkaç fikrin baskın olduğu görülmektedir. Öncelikle alternatif medyanın günlük rutini takip ederek günü 
ancak kurtardığı, ekstra bir iş yükü olarak görülen okuyucu/izleyici kaynaklı verinin kontrol edilmesi sürecine ayıracak kaynaklarının olmadığı ifade edilmektedir (K1). Íkinci olarak, Türkiye örnekleminde halen pasif bir okuyucu/izleyici algısı hâkim olduğundan, okuyucu/izleyici kitlenin de kendisinin habere bu şekilde müdahil olabileceği noktasında farkındalık eksikliğinden bahsedilmektedir (K5, K6). Özellikle hak ihlalleriyle ilgili haberlerde mağdurlar veya yakınlarının yayınlanmış veride düzeltme/eklemeler yaptığı görülse de, bu istisnai denebilecek bir katılımdır (K2). Ancak çoğu zaman okuyucunun haber süreçlerine katılımının önünün, zaten gazetecinin haberi yapış biçimiyle kapatılmış olduğu da dikkat çekmektedir. İncelenen projelerin hiçbirinde, okuyucunun haberin geliştirilmesi sürecine katılımı için araç veya fırsatlar sunulmamaktadır. Ancak İşçi Ölümleri Veritabanı ile Kadın Cinayetleri Haritası, interaktif arama olanağı ile okuyucunun kişiselleştirilmiş bir tüketim yapmasına olanak vermektedir (Tablo 4).

Bu bağlamda, okuyucu/izleyici kitlesinin haber yapım sürecine dâhil edilebilecek bir enformasyon kaynağından ziyade, alternatif fonlama kaynağı olarak algılandığını; ancak bu yönde de verimli girişimlerin olmadığını söylemek mümkündür.

\section{TARTIŞMA VE SONUÇ}

Katılımcılara veri gazeteciliğinin Türkiye örnekleminde demokrasi için barındırdığı fırsatlara dair görüşleri sorulduğunda ifade özgürlüğünün güçlendirilmesi, gazetecilere otosansürden azade bir hareket alanı yaratması, gazetecilik öğrencilerine, yeni mezunlara, işsiz veya son dönemde işinden çıkarılmış gazetecilere yeni bir iş alanı teşkil etmesi, toplumsal meselelere ışık tutması ve yurttaşların yaşam kalitesinin yükseltilmesi alanlarındaki potansiyeline değinmişlerdir. Bununla birlikte "açık veriye ulaşmanın temel bir hak olduğu" (Dusséaux, 2016; “From open data...," 2014) düsturundan hareketle, bu hakkın savunusunda önemli bir araç ve baskı mekanizması olarak da kabul edilmektedir. Bu hakka işlerlik kazandırmak daha fazla veri haberi yapılması yoluyla arz-talep dengesini zorlayarak mümkün olabilecektir. Ne var ki Türkiye örnekleminde veri gazeteciliğinin gelişimi ve demokratikleştirici potansiyelini yerine getirmesi önünde dört temel engelden bahsetmek mümkündür:

Illk olarak, dünyanın hemen her yerinde, veri gazeteciliği pratiğini az veya çok etkileyen, veriye erişim ve erişilen verinin niteliği işe ilgili sıkıntılar vardır. Sirkkunen (2011) Amerika, Arjantin ve İngiltere'deki durumu incelediği çalışmasında, veriyle ilgili sıkıntıları veriye erişim, erişilen verinin formatı, veri setindeki hatalar ve metadatanın 
bulunmayışı olarak sıralamaktadır. Bu sıkıntıların hepsi Türkiye'deki gazeteciler için de mevcuttur. Ayrıca verinin tekelleşmesi ile TÜiK'in metodolojisinden kaynaklanan sorunlar güvenilir veriye erişimi zorlaştırmaktadır. Bununla birlikte veri doğrulama gelişiyor olsa da halen kısıtlıdır ve kitlesel bir katıııma henüz ulaşabilmiş değildir.

Íkinci ana başlıkta medya yapısı ve ekonomi-politik yapıyla ilgili sıkıntılar vardır. Öncelikle büyük medya holdinglerinin ve bunlara bağlı medya kuruluşlarının henüz veri gazeteciliğinin farkında olmaması veya yayın politikaları gereği veriyi görmezden gelmeleri sayılabilir. Bu çok büyük bir okuyucu kitlesinin verinin sunduğu olanaklardan mahrum bırakılması anlamına gelmektedir. Aslında bu durum ekonomisi çok güçlü olmayan ülkeler için genel bir sorundur. Mesela Rodriguez (2015, p. 19) Uruguay'da özellikle ekonomik sıkıntıların yaşandığı dönemlerde, pek çok haber kuruluşunun “düşük bütçe" gerekçesiyle veriden kaçınmalarının bu pratik önündeki en önemli tehdit belirtmektedir. Keza Porlezza ve Splendore de (2019) İtalya'da veri gazeteciliğinin çok az gelişmiş olmasını ülkedeki politik, ekonomik yapıya, medya sistemine ve gazetecilerin eğitim sorunlarına bağlamaktadır. Bununla bağlantılı olarak, yelpazenin diğer tarafında konumlandırılabilecek alternatif medyayı da çok etkileyen yayın yasakları veya mahkemeler gibi sansür mekanizmalarını anmak gerekir. Özellikle yasal süreçlerin hesap soran gazetecilik yapmaya çalışan az sayıda gazeteciyi ve hatta bunların yaptıkları haber hikâyelerini paylaşan yurttaşları da sindirme aracı olarak kullanılmaya başlanması (Ataman \& Çoban, 2019) ifade özgürlüğü açısından büyük sorun teşkil etmektedir.

Üçüncü engel olarak, gazetecilerin çalışma şartlarıyla ilgili sıkıntılara değinmek mümkündür. Aslında çalışma koşullarıyla ilgili problemler Türkiye'ye özgü değildir. Batı veya küresel güney ülkelerinde de veri gazeteciliğinin önündeki çeşitli yapısal ve kurumsal engellerden bahsedilmektedir. Örneğin Rogers, Schwabish ve Bowers (2017), 2017 'de dünya genelinde veri gazeteciliğinin durumunu değerlendirdikleri raporlarında bu engelleri gazetecilerin bilgi ve beceri eksikliği, zaman baskısı, veri araçlarının teknolojinin hızına yetişemeyişi ve kurumların bu pratiğe yatııım yapmaktan kaçınması olarak sıralamaktadır. Katılımcılar tarafından da sıklıkla vurgulanan zaman kısıtının bazı büyük haber hikâyelerinin kaçırılmasına neden olduğu söylenebilir. Aslında çok büyük etkiler yaratabilecek veri hikâyeleri, zaman ayrılamadığı için yayınlananların araştırılıp bunlar hakkında daha derin analizler yapılması noktasında eksik kalmaktadır. Hikâyeler hep rakamlar ve istatistikler tarafından anlatıldığı, bir bağlama oturtulmadığı için yüzeyseldir. 
Araştırmacı veri gazeteciliği uzun süren ve emek yoğun bir çabadır. Bu nedenle sıkı bir takım çalışması gerektirmektedir. Veri gazeteciliğiyle ilgili temel kaynaklardan sayılabilecek Veri Gazeteciliği Elkitabı (Gray, Bounegru, \& Chambers, 2012) ABC, BBC, Chicago Tribune Guardian ve Zeit Online gibi haber merkezlerinin ürettiği başarılı veri gazeteciliği projelerinin ancak farklı becerilere sahip üyelerden oluşan, tam zamanlı veri ekiplerinin haber merkezi içindeki ve farklı haber merkezleriyle olan işbirliğinden ortaya çıktığını ortaya koymaktadır. Bu nedenle kapsamlı ve başarılı veri projeleri genellikle, ICIJ ağında üretilen Panama belgeleri haberlerinde olduğu gibi, farklı haber merkezleri arasındaki işbirliğiyle ortaya konabilen takım çalışmalarıdır. ICIJ'ın yanı sıra, The Organized Crime and Corruption Reporting Project, The African Forum for Investigative Reporting, The Arab Reporters for Investigative Journalism, The Global Investigative Journalism Network gibi pek çok araştırmacı gazeteciliği oluşumu, ortaklaşa araştırmacı veri haberi projeleri üretmektedir. Ne var ki Türkiye örnekleminde ekonomik şartlar gereği medya kuruluşlarının sadece veri haberi yapacak tam zamanlı personel istihdam etmedikleri anlaşılmaktadır. Gazetecileri yönlendirebilecek veriden ve onunla çalışmanın gerekliliklerinden anlayan veri editörlerinin de eksikliği hissedilmektedir. Bu nedenlerle analitik düşünebilen, deneyimli habercilerin bile çok az sayıda veri haberi üretebildiği görülmektedir. Ayrıca alanın işbirliklerine kapalı yapısı da pratiğin geliştirilmesinin önünde büyük bir engel teşkil etmektedir. Bazı meslek örgütleri ve haber organizasyonları tarafından gazeteciler için meslek içi eğitim faaliyetleri düzenlense de, katılımcıların pratikteki deneyimleri samimi bir işbirliği ortamına işaret etmemektedir. Bu noktada uluslararası ağlaşma ve işbirliği daha işlevsel gözükmektedir.

Yine bir başka fırsat olan, okuyucu/izleyici kitlesinden haber kaynağı olarak faydalanma anlamına gelen kitle kaynak kullanımı da, iş yükünü arttıracak, tasnif ve doğrulaması gerekecek kaygısıyla devreye sokulmamaktadır. Veri görselleştirilip çarpıcı şekilde okuyuculara/izleyicilere sunulsa da, hak ihlâlinin takibi, hikâyenin yargı ayağı vb. detaylar işgücü yetersizliği nedeniyle devam ettirilememekte, kamuoyunda tartışıması sağlanıp baskı mekanizmasına dönüştürülememektedir. Zaten gazetecilerin bu konudaki görev algısının düşüklüğü de, veri gazeteciliğinin kuramsal olarak dayandııılığı katılımcı ve güçlü demokrasi idealiyle örtüşmemektedir.

Son olarak toplum yapısı ve eğitim seviyesiyle ilgili sıkıntılardan bahsedilebilir. Veri gazeteciliği potansiyelini gerçekleştirmek için ihtiyaç duyduğu, örneğin The Guardian'ın milletvekillerinin masraflarıly ilgili "MPs expenses (milletvekili harcamaları)" (Rogers, 2009) veya La Nacion'un “Declaraciones Juradas abiertas (kamu çalışanlarının yeminli 
ifadeleri)" (Palomo, Teruel, \& Blanco-Castilla, 2019) haberlerinde olduğu gibi geniş ve adanmış okuyucu/izleyici kitlesinden yoksundur. Eğitim sistemi toplumun veriyle yakınlaşmasının önündeki en önemli engel olarak görünmektedir. Nitekim 2018 yılı PISA test sonuçları ${ }^{6}$, Türkiye'de temel eğitimin sonundaki öğrencilerin okuma, matematik ve fen alanlarında OECD ortalamasının altında kaldığını; matematikte $\% 36,7$, fende $\% 25,2$, okumada ise $\% 26,1$ oranında öğrencinin ise temel yeterlilik düzeyinde kaldıklarını göstermektedir (Öztürk, 2019). Bu eğitim sistemimizin analitik düşünen, günlük hayatta veriyi kullanabilen, rakamları okuma, hesaplama konularında yetkin bireyler yetiştirmek noktasındaki eksikliklerine de işaret etmektedir. Bu eğitimden devam eden kişilerin gazeteci olduklarında rakamlardan çekinme ve veriyi içselleştirememe sorunları yaşamaları kaçınılmazdır. Bu durumun gelişmekte olan ülkelerdeki sorunlarla benzerlik gösterdiği söylenebilir. Örneğin Zimbabwe'de "demokratik toplum ve bilgilenmiş yurttaş" varlığını sağlamanın bir yolu olarak veri gazeteciliğini incelediği çalışmasında Muneri (2019, p. 40), eğitim sistemindeki eksikliklerin, gazetecilerin veriyle olan ilişkileri önündeki bir engel olduğunu vurgulamaktadır. Nitekim gerçekleştirilen görüşmeler de, veri gazeteciliğinin daha ziyade teknik bir iş olarak görüldüğünden gazetecilerin gözünü korkuttuğuna işaret etmektedir. Benzer şekilde toplumun genelinde veri okuryazarlığının geliştirilmesi gereklidir, aksi takdirde bu pratik sadece kısıtlı bir çevreye hitap edebilecektir.

Araştırma Türkiye örnekleminde araştırmacı veri gazeteciliği pratiğinin zayıf kaldığını, daha ziyade sınırlı bir genel veri gazeteciliği yapıldığını ortaya koymaktadır. Bu durum veri gazeteciliğinin kuramsal tartışmada vurgulandığı gibi demokratikleştirici ve açık toplumu teşvik edici bir işlev yerine getirmesinin önünde engel teşkil etmektedir. Veri gazeteciliği yoluyla daha derinlikli araştırmalara dayanan, hesap soran haber hikâyelerinin üretilebilmesi için, haber merkezlerindeki ve haber merkezleri arasındaki takım çalışması teşvik edilmelidir. Gazetecilerin sosyal bilimler araştırmalarının perspektifi ile bilgisayar bilimlerindeki teknik ve analitik beceri setlerini bir araya getirmesinin fırsatları yaratılmalıdır.

Şeffaflığın sağlanması için sivil toplum ile devlet kurumlarının birlikte çalışması, önce her bir kurumun kendi içinde şeffaflaşması, iş dünyasından gazetecilere ve okuyucu/ izleyicilere kadar herkesin süreçlerde sorumluluk alması önemlidir. Bu sorumluluk kurumlardan hesap sorularak şeffaflaşmalarının talep edilmesi kadar, alternatif veri üretimini de kapsamaktadır. Sivil toplumun alternatif veri kaynakları olması, hem doğrulama açısından hem de işlevsizleşen bilgi edinme başvurularının aşılmassı açısından önemlidir. Ayrıca devlet kurumları Bilgi Edinme Hakkı'nın layıkıyla işleme konulması konusunda zorlanmalıdır. 
Okuyucuların veri toplamaya veya yayınlanan veri üzerine tartışması tartışıımaya başlansa da, okuyucuyu veri haberi süreçlerine dâhil etmek konusunda özel bir çaba gösterilmemektedir. Ne var ki demokrasinin daha müzakereci ve güçlü bir halini tesis etmek ancak kamusal tartışmanın güçlendirilmesi yoluyla mümkün olabilecektir. Bu konuda gazetecilerin bir sorumluluk alması gerekmektedir. Bunu sağlayabilmek için veri okuryazarlığının geliştirilmesi kaçınılmazdır. Bu gazetecilerin veriyi okumak ve analiz etmek konusundaki becerileri kadar, okuyucuların onu anlama kapasitesinin geliştirilmesini de kapsamaktadır. 2018 başında kurulan Veri Okuryazarlığı Derneği'nin bu yöndeki çalışmaları önemlidir.

Araştırma bulguları, Türkiye örnekleminde veri gazetecilerinin yurttaşları bilgilendirmek konusunda bir sorumluluk algısına sahip olsalar da, hesap soran bir gazetecilik yaparak dijital bekçi köpekleri olmaktan uzakta olduklarını ortaya koymaktadır. Bu noktada veri gazeteciliği demokrasiyi güçlendirici ve demokratik süreçleri teşvik edici bir işlev taşımamaktadır. Aynı zamanda gazeteci özerkliğini pekiştirecek, yurtdışında örnekleri görülen yurttaş katılımlı alternatif fonlama ve haber üretme mekanizmaları da henüz hayata geçirilebilmiş değildir. Katılımcılar tarafından vurgulanan koşullar yakın zamanda bu alanlarda olumlu bir gelişmeyi mümkün göstermemektedir. Ne var ki veri gazeteciliği pratiği, şeffaflık ve nesnelliği teşvik etmek, medyaya duyulan güveni tazelemek, kamu yararına çalışarak demokrasiyi, haber yapım ve finans süreçlerini dönüştürerek de gazeteci özerkliğini geliştirme hususlarında barındırdığı potansiyel nedeniyle geliştirilmeye ve ilgiye değer bir alandır. Bu konuda üretilen projeler arttıkça, Türkiye akademisinin de konuya daha fazla dâhil olarak somut öneriler geliştirmesi mümkün olacaktır. Bu araştırma, söz konusu potansiyelin hayata geçirilebilmesi konusunda öneriler sunan bir başlangıç çalışması niteliğindedir. Çalışmadaki kategorilerin her biri veri gazeteciliğinin üzerinde daha derinlikli düşünülmesi gereken boyutlarıdır ve farklı akademik araştırmalara konu edilmesinde fayda vardır.

\section{SON NOTLAR}

1 Araştırmacının kendisi de Dokuz8 Haber tarafından Mart 2018'de düzenlenen Veri Gazeteciliğine Giriş Eğitimi'ne katılarak gözlem yapma imkânı bulmuştur.

2 Makale Mayıs 2020 tarihinde tamamlanmıştır. Bu tarih itibarıyla ödüllere Türkiye'den başvuran toplam yedi proje bulunmaktadır. Ancak bunlardan biri (Noon Post) Arapça dilinde bir web sitesidir, bu nedenle analize dâhil edilmemiştir. Bu başvurulardan ikisi de Dağ Medya ile Açık 
Veri ve Veri Gazeteciliği Derneği'nin web siteleridir ve bunlar da analiz dışında bırakılmıştır. İncelenen sürede ödüllere 86 ülkeden başvuru yapılmıştır. Bunlardan sadece 36 tanesi Türkiye'den az başvuruya sahiptir. Aynı dönemde ödüllere Amerika'dan 507, Birleşik Krallık'tan 263, Almanya ve İspanya'dan 106, Hindistan'dan 77, Kanada'dan 67, İtalya'dan 65 başvuru yapıldığı bilgisi de Türkiye'deki üretimin ne kadar sınırlı olduğunu göstermek açısından önemlidir (Global Editors Network, nd).

3 Wayback Machine Internet Archive adlı kâr amacı gütmeyen kuruluş tarafından geliştirilen, web sayfalarının arşivlenmiş sürümlerine ulaşma olanağı sağlayan ücretsiz ve çevrimiçi bir arşivdir. https://archive.org/web/ adresinden ulaşılmaktadır.

4 Felle (2016) 17 ülkeden veri gazetecileriyle yapılan görüşmeleri içeren çalışmasında, dijital veri haberciliğinin gazeteciliğin geleneksel dördüncü güç işlevi üzerindeki etkisini tartışmakta, hesap soran bu gazetecilik pratiğini uygulayan gazetecileri de "dijital bekçi köpekleri" olarak nitelemektedir.

\section{Open Data Barometer - Leaders Edition.}

6 PISA testi, Ekonomik İşbirliği ve Kalkınma Örgütü (OECD) tarafından 3 yılda bir düzenlenmekte, 15 yaş grubu öğrencilerin bilgi ve becerileri seviyelerini değerlendirmektedir.

Hakem Değerlendirmesi: Dış bağımsız.

Çıkar Çatışması: Yazar çıkar çatışması bildirmemiştir.

Finansal Destek: Yazar bu çalışma için finansal destek almadığını beyan etmiştir.

Peer-review: Externally peer-reviewed.

Conflict of Interest: The author has no conflict of interest to declare.

Grant Support: The author declared that this study has received no financial support.

\section{KAYNAKLAR}

2 journalists were murdered - But their investigations live on. (2019, April 7). DW Freedom. Retrieved from https://www.dw.com/en/2-journalists-were-murdered-but-their-investigations-live-on/a-48241808

A world that counts mobilising the data revolution for sustainable development. (2014). United Nations. Retrieved from https://www.undatarevolution.org/wp-content/uploads/2014/12/A-World-That-Counts2.pdf

Akdeniz, Y., \& Güven, O. (2019). Engelli web 2018 raporu. Retrieved from https://privacy.cyber-rights.org.tr/wpcontent/uploads/2019/06/EngelliWeb_2018.pdf 
Aktan, S. (2018, December 3). TÜíK ve güven tartışmaları: Enflasyondaki olumlu trend gerçek mi yapay mı? Euronews. Retrieved from https://tr.euronews.com/2018/12/03/tuik-ve-guven-tartismalar-enflasyondakiolumlu-trend-gercek-mi-yapay-mi

Arthur, C. (2010, November 22). Analysing data is the future for journalists, says Tim Berners-Lee. The Guardian Online. Retrieved from https://www.theguardian.com/media/2010/nov/22/data-analysis-tim-berners-lee

Ataman, B., \& Çoban, B. (2019). How to deal with threats to journalism? In E. Eide, K. S. Orgeret, \& N. Mutluer (Eds.), Transnational Othering Global Diversities: Media, Extremism and Free Expression (pp. 171-190). Gothenburg, Sweden: Nordicom.

Baack, S. (2011). A new style of news reporting: Wikileaks and data-driven journalism. Cyborg Subjects. Retrieved from https://www.ssoar.info/ssoar/handle/document/40025

Baack, S. (2015). Datafication and empowerment: How the open data movement re-articulates notions of democracy, participation, and journalism. Big Data \& Society, July-December 2015, 1-11. https://doi. org/10.1177/2053951715594634

Berger, A. A. (1998). Media Research Techniques. London, UK: Sage Publications.

Borges-Rey, E. (2016). Unravelling data journalism. A study of data journalism practice in British newsrooms. Journalism Practice, 10(7), 833-843. https://doi.org/10.1080/17512786.2016.1159921

Boyles, J. L., \& Meyer, E. (2016). Letting the data speak. Digital Journalism, 4(7), 944-954. https://doi.org/10.1080/ 21670811.2016.1166063

Carlsson, U., \& Pöythari, R. (2017). Words of introduction. In U. Carlsson, \& R. Pöhtyari (Eds.), The Assault on Journalism (pp. 11-17). Gothenburg, Sweden: Nordicom.

Dağ, P., \& Demirel, S. (2016, November 25). İmam hatip liselerinin son 10 yılı. Bağımsız Gazetecilik Platformu. Retrieved from http://platform24.org/haber-arastirma/1883/imam-hatip-liselerinin-son-10-yili

Doğu, B. (2015). Veri haberciliği: Demokratik medya için olanaklar. Folklor/Edebiyat, 21(83), 181-197.

Dusséaux, A. (2016, July 27). Open data as a human right: The case of case-law [Web log post]. Retrieved from https://blog.okfn.org/2016/07/27/open-data-as-a-human-right-the-case-of-case-law/

Erkmen, Ö. (2018). Büyük veri ve gazetecilik: Veri gazeteciliği demokrasi, katılım ve gazeteciliğe dair anlayışımızı nasıl dönüştürebilir? Akdeniz Üniversitesi Illetişim Fakültesi Dergisi, 30, 322-344. https://doi.org/10.31123/akil.464511

Esser, F., \& Neuberger, C. (2019). Realizing the democratic functions of journalism in the digital age: New alliances and a return to old values. Journalism, 20(1) 194-197. https://doi.org/10.1177/1464884918807067

Felle, T. (2015). Accountability meets engagement: data journalism's watchdog role? In T. Felle, J. Mair, \& D. Radcliffe (Eds.), Data Journalism: Inside the Global Future (pp. 167-176). Suffolk, UK: Abramis Academic.

Felle, T. (2016). Digital watchdogs? Data reporting and the traditional 'fourth estate' role for journalists. Journalism Theory, Practice and Criticism, 17(1), 85-96. https://doi.org/10.1177/1464884915593246

Freedom on the Net 2019. (2019). Freedom House. Retrieved from https://www.freedomonthenet.org/country/ turkey/freedom-on-the-net/2019 
From open data to a right to data: A response to the UN data revolution report web foundation (2014, December 9). Web Foundation. Retrieved from https://webfoundation.org/2014/12/from-open-data-to-a-right-todata-a-response-to-the-un-data-revolution-report/

Global Editors Network. (n.d.). Global Editors Network - Community. Retrieved from http://community. globaleditorsnetwork.org/projects

Gray, J., Bounegru, L., \& Chambers, L. (2012). The Data Journalism Handbook. Cambridge, UK: O'Reilly.

Hewett, J. (2013). Learning in progress. From computer-assisted reporting to data journalism, via freedom of information, open data and more. In J. Mair, R. L. Keeble, P. Bradshaw, \& T. Beleaga (Eds.), Data Journalism: Mapping the Future (pp. 3-14). Suffolk, UK: Abramis Academic.

Howard, A. B. (2014). The Art and Science of Data Driven Journalism. Columbia, USA: Columbia University Academic Commons.

Karlsen, J., \& Stavelin, E. (2014). Computational journalism in Norwegian newsrooms. Journalism Practice, 8(1), 34-48. https://doi.org/10.1080/17512786.2013.813190

Knight, M. (2015). Data journalism in the UK: a preliminary analysis of form and content. Journal of Media Practice, 16(1), 55-72. https://doi.org/10.1080/14682753.2015.1015801

Kubzansky, C. (2018, August 8). Nine essential tools from ICIJ's data journalism and programming experts. [Web log post]. Retrieved from https://www.icij.org/blog/2018/08/nine-essential-tools-from-icijs-datajournalism-and-programming-experts/

Lewis, S. C. (2015). Journalism in an era of big data. Digital Journalism, 3(3), 321-330. https://doi.org/10.1080/216 70811.2014 .976399

Loosen, W., Reimer, J., \& Schmidt, F. (2015, September). When Data Become News. A content analysis of data journalism pieces. Paper presented at The Future of Journalism: Risks, Threats and Opportunities Conference, Cardiff University, UK. Retrieved from https://www.academia.edu/16029530/When_data_become_ news._A_content_analysis_of_data_journalism_pieces

Lorenz, M., Kayser, N., \& McGhee, G. (2011). Media companies must become trusted data hubs. EJC Magazine. Retrieved from https://ejc.net/magazine/article/media-companies-must-becometrusted-data-hubs

Lune, H., \& Berg, H. L. (2017). Qualitative Research Methods for the Social Sciences. Essex, UK: Pearson.

Mair, J., \& Keeble, R. L. (2013). Data Journalism: Mapping the Future. Suffolk, UK: Abramis Academic.

Manuli, G. (2013, April 5). IndieGoGo founder on raising money for journalism projects:'People fund people, not just ideas'. International Journalists Network. [Web log post]. Retrieved from https://ijnet.org/en/story/ indiegogo-founder-raising-money-journalism-projects-people-fund-people-not-just-ideas

Media Ownership Monitor. (2019). Medya Sahipleri. Media Ownership Monitor Türkiye. Retrieved from https:// turkey.mom-rsf.org/

Muneri, C. T. (2019). Prospects for data journalism in Zimbabwe: Challenges of engendering a democratic society and an informed citizenry in the digital age. In B. Mutsvairo, S, Bebawi, \& E. Borges-Rey (Eds.), Data Journalism in the Global South (pp. 39-52). Cham, Switzerland: Palgrave Macmillan. 
Mutsvairo, B. (2019). A new dawn for the "developing" world? Probing data journalism in non-western societies. In B. Mutsvairo, S, Bebawi, \& E. Borges-Rey (Eds.), Data Journalism in the Global South (pp. 1-20). Cham, Switzerland: Palgrave Macmillan.

Mutsvairo, B., Bebawi, S., \& Borges-Rey, E. (2019). Data Journalism in the Global South. Cham, Switzerland: Palgrave Macmillan.

Narin, B., Ayaz, B., Fırat, F., \& Fırat, D. (2017). Büyük veri ve gazetecilik ilişkisi bağlamında veri gazeteciliği. AJIT-e: Online Academic Journal of Information Technology, 8(30), 215-235.

Open Data Barometer (2017). The Open Data Barometer. Retrieved from https://opendatabarometer.org/?_ year=2017\&indicator $=$ ODB

Open Knowledge Foundation. (n.d.). What is open? Retrieved from https://okfn.org/opendata/

Open Knowledge International. (2016). Global Open Data Index. Retrieved from https://index.okfn.org/place/tr/ Özkan, Ö. (2019). Açık Veri. İstanbul, Turkey: Türkiye Bilişim Vakfı.

Öztürk, F. (2019, December 3). PISA testi 2018 sonuçları açıklandı:Türkiye yine tüm alanlarda OECD ortalamasının altında. BBC Türkçe. Retrieved from https://www.bbc.com/turkce/haberler-turkiye-50639723

Palomo, B., Teruel, L., \& Blanco-Castilla, E. (2019). Data journalism projects based on user-generated content: How La Nacion data transforms active audience into staff. Digital Journalism, 7(9), 1270-288. https://doi.org/ 10.1080/21670811.2019.1626257

Panama Belgeleri haberlerine erişim engeli: Diken'in Mehmet Cengiz haberine sansür. (2016, July 1). Diken. Retrieved from http://www.diken.com.tr/dikenin-de-aralarinda-bulundugu-bes-sitedeki-panama-belgelerihaberlerine-erisim-engeli/

Paraise, S., \& Dagiral, E. (2012). Data-driven journalism and the public good: 'Computer-assisted reporters' and 'programmer-journalists' in Chicago. New Media \& Society, 15(6), 853-871. https://doi.org/10.1177/1461444812463345

Porlezza, C., \& Splendore, S. (2019). From open journalism to closed data: Data journalism in Italy. Digital Journalism, 7(9), 1230-1252. https://doi.org/10.1080/21670811.2019.1657778

Rodriguez, L. (2015). Data journalism in Uruguay. Retrieved from https://www.researchgate.net/ publication/291692546_Data_Journalism_in_Uruguay

Rogers, S. (2009, June 18). How to crowdsource MPs' expenses. The Guardian Datablog. Retrieved from https:// www.theguardian.com/news/datablog/2009/jun/18/mps-expenses-houseofcommons

Rogers, S. (2013). Facts Are Sacred: The Power of Data. London, UK: Faber \& Faber.

Rogers, S., Schwabish, J., \& Bowers, D. (2017). Data journalism in 2017. Retrieved from https://newslab. withgoogle.com/assets/docs/data-journalism-in-2017.pdf

Sirkkunen, E. (2011). Trends in Data Journalism. The Next Media Programme of TIVIT Report. Retrieved from // virtual.vtt.fi/virtual/nextmedia/Deliverables-2011/D3.2.1.2.B_Hyperlocal_Trends_In\%20Data_Journalism.pdf

Stalph, F., \& Borges-Rey, E. (2018). Data journalism sustainability. Digital Journalism, 6(8), 1078-1089. https://doi.org/10.1080/21670811.2018.1503060 
Strauss, A., \& Corbin, J. (2014). Basics Of Qualitative Research Techniques. New York, USA: Sage Publications.

Tabari, C., Provost, A., \& Trottier, A. (2016). Data journalism's actors, practices and skills: A case study from Quebec. Journalism, 17(1), 66-84. https://doi.org/10.1177/1464884915593245

Tandoc, E. C., \& Oh, S. (2017). Small departures, big continuities? Journalism Studies, 18(8), 997-1015. https://doi. org/10.1080/1461670X.2015.1104260

Vanderstoep, S. W., \& Johnston, D. D. (2009). Research Methods for Everyday Life Blending Qualitative and Quantitative Approaches. San Francisco, USA: Jossey-Bass.

Wright, K., Zamith, R., \& Bebawi, S. (2019). Data journalism beyond majority world countries: Challenges and opportunities. Digital Journalism, 7(9), 1295-1302. doi: 10.1080/21670811.2019.1702472

Young, M. L., Hermida, Al. \& Fulda, J. (2018). What Makes for Great Data Journalism?, Journalism Practice, 12(1), 115-135. https://doi.org/10.1080/17512786.2016.1270171

Zamith, R. (2019). Transparency, interactivity, diversity, and information provenance in everyday data journalism. Digital Journalism, 7(4), 470-489. https://doi.org/10.1080/21670811.2018.1554409 


\section{TABLOLAR VE ŞEKILLER}

Tablo 1: Katılımcı Listesi

\begin{tabular}{|l|c|c|c|c|}
\hline Katılımcı & Cinsiyet & Çalışılan kurum & Kurumdaki rolü & Görüşme süresi \\
\hline K1 & Erkek & Çevrimiçi & Yönetici, editör & $75 \mathrm{dk}$. \\
\hline K2 & Kadın & Bağımsız veri projesi & Muhabir & $59 \mathrm{dk}$. \\
\hline K3 & Kadın & Gazete & Editör & $62 \mathrm{dk}$. \\
\hline K4 & Erkek & Gazete \& Çevrimiçi & Editör & $30 \mathrm{dk}$. \\
\hline K5 & Erkek & Çevrimiçi & Muhabir & $65 \mathrm{dk}$. \\
\hline K6 & Kadın & Bağımsız veri projesi & Muhabir & $67 \mathrm{dk}$. \\
\hline K7 & Erkek & Çevrimiçi & Yönetici, eğitmen & $50 \mathrm{dk}$. \\
\hline K8 & Kadın & Freelance & Muhabir & $55 \mathrm{dk}$. \\
\hline
\end{tabular}

Tablo 2: Görüşme Kılavuzu

\begin{tabular}{|c|c|}
\hline \multirow{3}{*}{$\begin{array}{l}\text { Katılımcı hakkında } \\
\text { bilgiler }\end{array}$} & Eğitim, mesleki geçmişi, dijital okuryazarlık seviyesi \\
\hline & Çalıştığı kurum, kurumdaki görevi \\
\hline & Veri gazeteciliğine yönelik ilgi \\
\hline \multirow{6}{*}{ Rol/görev algısı } & Veri gazeteciliği tanımı \\
\hline & Veri gazetecisinin yetenek ve yeterlilikleri \\
\hline & Toplumdaki görevi / işlevleri \\
\hline & Geleneksel gazeteciliğe göre avantajları \\
\hline & Dış etkileri (kullanıcı ve topluma faydası, bilgi edinme hakkı, şeffaflık, demokrasi) \\
\hline & Yurt dışındaki uygulamalar \\
\hline \multirow{9}{*}{$\begin{array}{l}\text { Üretim süreç ve } \\
\text { uygulamaları }\end{array}$} & Haber ekibinin yapısı ve büyüklüğü \\
\hline & İş akışı, iş bölümü, editoryal süreç \\
\hline & Çalışılan kurumda veri gazeteciliğinin yeri \\
\hline & Hikâye seçimini etkileyen faktörler \\
\hline & Veri kaynakları \\
\hline & Açık veri, Bilgi Edinme Hakkı \\
\hline & Veri güvenilirliği, doğrulama \\
\hline & Verinin sunumu, kullanılan araçlar \\
\hline & Karşılaşılan sorunlar \\
\hline \multirow{6}{*}{$\begin{array}{l}\text { Okuyucu/izleyici } \\
\text { algısı ve okuyucuyu } \\
\text { dâhil etme çabası }\end{array}$} & Okuyucu kitlesi \\
\hline & Etkileşim olanakları ve okuyucunun haber süreçlerine katılımı \\
\hline & Kamusal tartışma \\
\hline & Kitle kaynak kullanımı, kitle fonlama \\
\hline & Dijital okuryazarlık \\
\hline & Karşılaşılan sorunlar \\
\hline \multirow{4}{*}{$\begin{array}{l}\text { Potansiyel algısı, } \\
\text { öngörü ve öneriler }\end{array}$} & Çalışılan kurumdaki gelişimi \\
\hline & Geleceğine dair öngörüler \\
\hline & Geliştirme önerileri \\
\hline & Meslek içi eğitimler \\
\hline
\end{tabular}


Tablo 3: Veri Gazeteciliği Ödüllerine Türkiye'den Başvuran Projeler

\begin{tabular}{|c|c|c|c|c|c|}
\hline Yוl & $\begin{array}{c}\text { Başvuran } \\
\text { kişi / kurum }\end{array}$ & $\begin{array}{c}\text { Haber } \\
\text { merkezi } \\
\text { / ekip } \\
\text { büyüklüğü }\end{array}$ & $\begin{array}{c}\text { Başvuru } \\
\text { kategorisi }\end{array}$ & Başlık / tanım & URL \\
\hline 2013 & \multicolumn{5}{|c|}{2013 yılında ödüllere Türkiye'den başvuru olmamıştır. } \\
\hline 2014 & \multicolumn{5}{|c|}{2014 yılında ödüllere Türkiye'den başvuru olmamıştır. } \\
\hline 2015 & $\begin{array}{l}\text { Dağ Medya } \\
\text { - Pınar Dağ } \\
\text { (Kurucu) }\end{array}$ & Küçük & $\mathrm{N} / \mathrm{A}$ & $\begin{array}{c}\text { Türkiye'deki işçi ölümleri } \\
\text { açık veri tabanı }\end{array}$ & \\
\hline 2016 & $\begin{array}{l}\text { Dağ Medya } \\
\text { - Pınar Dağ } \\
\text { (Kurucu) }\end{array}$ & Küçük & $\begin{array}{c}\text { Yılın veri } \\
\text { gazeteciliği } \\
\text { websitesi }\end{array}$ & $\begin{array}{c}\text { Dağ Medya } \\
\text { websitesinde veri } \\
\text { haberleri yayınlamakta } \\
\text { ve gazeteciler için } \\
\text { eğitim ve çalıştaylar } \\
\text { düzenlemektedir. }\end{array}$ & www.dagmedya.net \\
\hline 2016 & $\begin{array}{l}\text { Bağımsız } \\
\text { - Ceyda } \\
\text { Ulukaya } \\
\text { (Kurucu) }\end{array}$ & $\mathrm{N} / \mathrm{A}$ & $\mathrm{N} / \mathrm{A}$ & $\begin{array}{l}\text { Türkiye'deki kadın } \\
\text { cinayetleri haritası }\end{array}$ & www.kadincinayetleri.org \\
\hline \multirow[t]{2}{*}{2016} & \multirow[t]{2}{*}{$\begin{array}{l}\text { School of } \\
\text { Data Turkey }\end{array}$} & \multirow[t]{2}{*}{ Küçük } & $\begin{array}{c}\text { Yılın veri } \\
\text { gazeteciliği } \\
\text { websitesi }\end{array}$ & \multirow[t]{2}{*}{$\begin{array}{l}\text { Türkiye Açık Veri ve Veri } \\
\text { Gazeteciliği Derneği }\end{array}$} & \multirow[t]{2}{*}{ www.avvg.org.tr } \\
\hline & & & Açık veri & & \\
\hline \multirow[b]{2}{*}{2017} & \multirow[b]{2}{*}{$\begin{array}{l}\text { Turkey } \\
\text { Blocks - } \\
\text { Alp Toker } \\
\text { (Kurucu) }\end{array}$} & \multirow[b]{2}{*}{ Küçük } & $\begin{array}{c}\text { Yılın } \\
\text { araştırması }\end{array}$ & \multirow{2}{*}{$\begin{array}{c}\text { Turkey Blocks veriye } \\
\text { dayalı, gerçek zamanlı bir } \\
\text { sansür ve dijital şeffaflık } \\
\text { izleme projesidir. } \\
\text { Türkiye'deki kitlesel } \\
\text { sansür vakalarını takip } \\
\text { eder. }\end{array}$} & \multirow[b]{2}{*}{ www.turkeyblocks.org } \\
\hline & & & $\begin{array}{l}\text { Flaş haber } \\
\text { hikayesinde } \\
\text { en iyi veri } \\
\text { kullanımı }\end{array}$ & & \\
\hline 2017 & $\begin{array}{l}\text { Noon Post - } \\
\text { Muhammad } \\
\text { Basheer } \\
\text { (CEO \& } \\
\text { Kurucu) }\end{array}$ & Küçük & $\mathrm{N} / \mathrm{A}$ & $\begin{array}{c}\text { Noon Post Arap } \\
\text { dünyasından Arapça } \\
\text { dilindeki ilk veri } \\
\text { gazeteciliği projesidir. } \\
\text { Mısır'da ekonomi, siyaset } \\
\text { ve ordu arasındaki } \\
\text { ilişkileri göstermeyi } \\
\text { amaçlamaktadır. }\end{array}$ & www.noonpost.com \\
\hline \multirow[b]{2}{*}{2017} & \multirow{2}{*}{\begin{tabular}{|c|} 
Dağ Medya \\
- Pınar Dağ \\
(Kurucu) \\
\& Sadettin \\
Demirel (Veri \\
Muhabiri) \\
\end{tabular}} & \multirow[b]{2}{*}{ Küçük } & $\begin{array}{c}\text { Yılın } \\
\text { araştırması }\end{array}$ & \multirow{2}{*}{$\begin{array}{c}\text { Türkiye'de İmam } \\
\text { Hatip Liselerinin son } \\
\text { on yıldaki durumunu } \\
\text { incelemektedir. }\end{array}$} & \multirow[b]{2}{*}{ www.dagmedya.net } \\
\hline & & & $\begin{array}{l}\text { Küçük haber } \\
\text { merkezi }\end{array}$ & & \\
\hline 2018 & \multicolumn{5}{|c|}{2018 yılında ödüllere Türkiye'den başvuru olmamıştır. } \\
\hline 2019 & \multicolumn{5}{|c|}{2019 yılında ödüllere Türkiye'den başvuru olmamıştır. } \\
\hline
\end{tabular}

Kaynak: http://community.globaleditorsnetwork.org/projects 
Tablo 4: Veri Gazeteciliği Ödüllerine Başvuran Projelerin Analiz Bulguları

\begin{tabular}{|c|c|c|c|c|c|}
\hline \multicolumn{2}{|c|}{$\begin{array}{l}\text { VERI PROJESININ SAHIBi / } \\
\text { BAŞLIĞI / TARIHI }\end{array}$} & \multirow{2}{*}{\begin{tabular}{|c|}
$\begin{array}{c}\text { Dağ Medya - } \\
\text { Türkiye'deki } \\
\text { işçi ölümleri } \\
\text { açık veri tabanı } \\
(2015)\end{array}$ \\
$\begin{array}{c}\text { İnsan hakları - } \\
\text { iş kazaları }\end{array}$ \\
\end{tabular}} & \multirow{2}{*}{$\begin{array}{c}\text { Kadincinayetleri.org } \\
\text { - Türkiye'deki kadın } \\
\text { cinayetleri haritası } \\
(2016)\end{array}$} & \multirow{2}{*}{$\begin{array}{c}\text { Turkey Blocks - } \\
\text { Türkiye'deki kitlesel } \\
\text { sansür vakaları } \\
\text { takip (2017) } \\
\text { İnsan hakları - } \\
\text { ifade özgürlüğü ve } \\
\text { sansür }\end{array}$} & \multirow{2}{*}{$\begin{array}{l}\text { Dağ Medya - } \\
\text { Türkiye'de İmam } \\
\text { Hatip Liselerinin } \\
\text { son on yıldaki } \\
\text { durumu (2017) } \\
\text { İnsan hakları - } \\
\text { eğitim hakkı ve } \\
\text { azınlık hakları }\end{array}$} \\
\hline \multirow{4}{*}{ İ̧̧ERIK } & Konular & & & & \\
\hline & $\begin{array}{c}\text { Veri } \\
\text { kaynakları }\end{array}$ & $\begin{array}{l}\text { Bilgi Edinme } \\
\text { başvurusu } \\
\text { (kapsamlı } \\
\text { yanıtlar } \\
\text { alınamamıştır) } \\
\text { Medya takibi }\end{array}$ & $\begin{array}{c}\text { Bilgi Edinme } \\
\text { başvurusu (sonuçsuz } \\
\text { kalmıştır) } \\
\text { Bianet Erkek Şiddeti } \\
\text { Çetelesi }\end{array}$ & $\begin{array}{c}\text { Raspberry Pi ağı } \\
\text { Websitesi ziyaretçi } \\
\text { logları } \\
\text { Resmi Gazete }\end{array}$ & $\begin{array}{l}\text { Bilgi Edinme } \\
\text { başvurusu } \\
\text { (kapsamlı yanıtlar } \\
\text { alınamamıştır) } \\
\text { Görüşmeler } \\
\text { Raporlar } \\
\text { Soru önergeleri } \\
\text { Medya takibi }\end{array}$ \\
\hline & $\begin{array}{l}\text { Etkisi/ } \\
\text { amacı }\end{array}$ & $\begin{array}{l}\text { Veri tabanı } \\
\text { Şeffaf istatistik } \\
\text { sağlamak } \\
\text { Politika } \\
\text { yapıcılara } \\
\text { referans } \\
\text { sunmak }\end{array}$ & $\begin{array}{c}\text { Veri tabanı } \\
\text { Arşiv } \\
\text { Saklanan } \\
\text { istatistikleri ifşa } \\
\text { etmek } \\
\text { Meseleyi görünür } \\
\text { kılmak } \\
\text { Çözüm önerileri } \\
\text { geliştirmek için bir } \\
\text { araç sunmak }\end{array}$ & $\begin{array}{l}\text { Resmi anlatıya } \\
\text { meydan okumak } \\
\text { Yurttaşların } \\
\text { çevrimiçi } \\
\text { kalabilmesini } \\
\text { sağlamak } \\
\text { Dijital tehdit riski } \\
\text { altındaki grupları } \\
\text { desteklemek }\end{array}$ & $\begin{array}{l}\text { Meseleyi görünür } \\
\text { kılmak }\end{array}$ \\
\hline & $\begin{array}{l}\text { Veri setleri } \\
\text { açık mı? }\end{array}$ & Evet & & & Evet \\
\hline \multirow{10}{*}{$\begin{array}{l}\text { GÖRSEL } \\
\text { / TEKNIK } \\
\text { UNSURLAR }\end{array}$} & Harita & Evet & Evet & Evet & Evet \\
\hline & Tablo & & & Evet & Evet \\
\hline & Grafik & Evet & Evet & Evet & Evet \\
\hline & $\begin{array}{l}\text { Zaman } \\
\text { çizelgesi }\end{array}$ & & & & Evet \\
\hline & Infografik & & & & \\
\hline & $\begin{array}{l}\text { Sayaç/ } \\
\text { istatistik }\end{array}$ & Evet & Evet & & \\
\hline & Veri tabanı & Evet & & & \\
\hline & Fotoğraf & & & Evet & Evet \\
\hline & Video & & & Evet & \\
\hline & $\begin{array}{c}\text { Interaktif } \\
\text { arama }\end{array}$ & Evet & Evet & & \\
\hline $\begin{array}{l}\text { KULLANILAN } \\
\text { VERI } \\
\text { ARAÇLARI }\end{array}$ & & $\begin{array}{c}\text { MySQL } \\
\text { Google Maps } \\
\text { Fusion Tables } \\
\text { datawrapper.de }\end{array}$ & $\begin{array}{c}\text { Google araması } \\
\text { Excel } \\
\text { Ruby } \\
\text { Javascript }\end{array}$ & $\begin{array}{l}\text { Raspberry Pi } \\
\text { InfluxDB } \\
\text { Intel NUC }\end{array}$ & $\begin{array}{c}\text { Tabula } \\
\text { Open Refine } \\
\text { Tableau } \\
\text { Google } \\
\text { Spreadsheets }\end{array}$ \\
\hline \multicolumn{6}{|c|}{$\begin{array}{l}\text { ERIŞiM ADRESI } \\
\text { http://community.globaleditorsnetwork.org/content/open-database-deceased-workers-turkey-0 } \\
\text { http://community.globaleditorsnetwork.org/content/femicide-map-turkey-0 } \\
\text { http://community.globaleditorsnetwork.org/content/turkey-blocks-realtime-mass-censorship-reporting- } \\
\text { platform-0 } \\
\text { http://community.globaleditorsnetwork.org/content/analysing-turkish-imam-hatip-high-schools-over-past- } \\
\text { decade-0 }\end{array}$} \\
\hline
\end{tabular}


